\title{
IDENTIFYING RURAL ROADS
}

\author{
ALAN ROMERO*
}

There are over four million miles of roads in the United States. ${ }^{1}$ Over twothirds of them are local roads. ${ }^{2}$ About half of them aren't paved. ${ }^{3}$ Those are the kinds of roads this Article is about. Some of those local, unpaved roads can hardly even be recognized as roads. They may be used very little or not at all. They may have been used long ago but aren't used anymore. They may have been created expecting growth that never happened.

When a road is established, built, used, and maintained, it's pretty easy to recognize the road and determine rights and duties in relation to the road. But when a road isn't clearly established, was never really built, has hardly been used, or hasn't been maintained, it can be pretty hard to know who has what rights and duties in relation to the road. In this Article, I describe and evaluate the rules regarding the creation and elimination of public roads, particularly county roads, which vary considerably across the country. I identify rules that can help resolve the problem of uncertainty about the legal status of roads, and rules that contribute to the problem, or at least miss the opportunity to reduce the problem. Part I examines how the government may acquire public roadways and how government ownership may be uncertain. Part II discusses legal requirements to legally establish a public road. If a road was not properly established, it may not be a public road after all. Part III addresses statutory road mapping processes that may be an alternative way to create or vacate public roads, potentially significantly reducing uncertainty about public roads. Part IV considers legal requirements for giving notice that a road has been established. If required notice isn't given, the private landowner may not be subject to the road. Part V discusses the rules regarding abandoning or vacating public roads.

\section{ACQUIRING A ROADWAY}

In order to establish a public road, the government must both acquire an interest in the land and do whatever the law requires to establish that interest as a public road. ${ }^{4}$ Acquiring an interest in land alone doesn't necessarily establish a public road. ${ }^{5}$ Nor does establishing a road necessarily acquire an interest in the

* Carl M. Williams Professor of Law and Social Responsibility and Director of Rural Law Center, University of Wyoming College of Law. B.A. 1990, Brigham Young University; J.D. 1993, Harvard Law School. Thanks to Doug Brodbeck for research assistance.

1. Robert W. Burchell et al., Infrastructure Need in the United States, 2010-2030: What is the Level of Need? How Will it Be Paid For?, 42-43 UrB. LAw. 41, 55 (2011).

2. Id.

3. $I d$.

4. See, e.g., Cary v. Pulaski Cty. Fiscal Ct., 420 S.W.3d 500, 515-16 (Ky. Ct. App. 2013) (distinguishing the establishment of a road by government resolution and the acquisition of an interest in the land by contract, condemnation, or otherwise).

5. See, e.g., Yeager v. Forbes, 78 P.3d 241, 255 (Wyo. 2003) (applying statute that declared no road was a public road unless established as required by the statute). 
land. ${ }^{6}$ Sometimes courts seem to overlook this point, treating acquisition and establishment as a single act. ${ }^{7}$ Likewise, declaring or establishing a public road does not implicitly take the property interest needed for the road. ${ }^{8}$ This part discusses the first of these essential requirements for establishing a public road: acquiring an interest in land.

The government may establish a road on land that it owns or on land owned by someone else but over which the government has an easement, or right-ofway. ${ }^{9}$ When a deed or other legal instrument gives or reserves an interest in land for a roadway, courts generally seem to favor finding an easement rather than fee simple ownership of the roadway. ${ }^{10}$ Because an easement accomplishes the purpose of such an instrument, construing an ambiguous instrument to give the government fee simple is not necessary to accomplish the parties' purpose. ${ }^{11}$

The government may acquire the necessary property interest, whether easement or fee simple, by purchase, condemnation, dedication, or prescription/adverse possession. ${ }^{12}$

\section{A. Purchase or Condemnation}

The government may negotiate the purchase of an easement from a private

6. See Cary, 420 S.W.3d at 515.

7. See, e.g., Kratina v. Bd. of Comm'rs, 548 P.2d 1232, 1235 (Kan. 1976) (“In Kansas as elsewhere a public roadway may be established in three different ways: by purchase or condemnation, by prescription, or by dedication.").

8. See Cary, 420 S.W.3d at 515 ("[A]n order merely 'establishing' a county road has no bearing upon whether a county has the right to possess, control, or maintain real property constituting a road; it 'simply identif[ies] the new roadway ultimately to be established when necessary further procedural steps have been taken." (citation omitted)).

9. See, e.g., 39 Am. Jur. 2D Highways, Streets, and Bridges $§ 127$ (2020) ("While the public right or interest in public highways, roads, and streets is generally an easement, with the fee vested in the abutting landowners, public highways or roads may vest in the state, county, or municipality by fee under a conveyance so providing.").

10. See, e.g., Greaves v. McGee, 492 So. 2d 307, 312 (Ala. 1986) (holding that, considering purpose of the instrument as a whole, county acquired an easement by a deed conveying "all of our right, title, interest and claim in and to the following strip of land twenty feet wide to be used for the purpose of constructing a road"); Bumgarner v. Bumgarner, 862 P.2d 321, 325-26, 329 (Idaho Ct. App. 1993) (holding that deed reserved an easement by describing the land conveyed "less a strip of land twenty-five feet wide on south side of said described land which is reserved for the purpose of giving passage or right of way for a roadway"); JON W. BRUCE \& JAMES W. ELY, JR., THE LAW OF EASEMENTS \& LiCENSES IN LAND § 1:24 (2020).

11. See, e.g., Bashaw v. Clark, 699 N.Y.S.2d 533, 536 (App. Div. 1999) (“However, '[t]he law will not, by construction, effect $* * *$ a grant of a greater interest or estate than was essential to the public use for which the grant was sought."' (citation omitted)).

12. See, e.g., Kratina, 548 P.2d at 1235; Terry v. City of Independence, 388 S.W.2d 769, 774 (Mo. 1965); Ford v. Dickerson, 662 S.E.2d 503, 506 (W. Va. 2008). 
landowner. ${ }^{13}$ But even if a landowner doesn't want to sell an easement, the government may forcibly buy an easement by the exercise of eminent domain, which requires the government to pay just compensation. ${ }^{14}$ Even if the government doesn't formally exercise eminent domain to acquire a roadway easement, it nevertheless takes an easement if it "authorizes and proceeds with the construction of a public road through privately owned property without first securing title or an easement to it." ${ }^{15}$ Mere declaration of a road generally doesn't take land because it doesn't invade the owner's possession of the land, ${ }^{16}$ but building a road is obviously a physical invasion that takes the private property upon which the road is built. ${ }^{17}$ In such circumstances, the landowner may initiate a lawsuit in inverse condemnation to recover just compensation for the taken easement. ${ }^{18}$

\section{B. Dedication}

Dedication is the voluntary grant of an easement or title by the landowner. ${ }^{19}$ Statutory dedications may dedicate an easement or ownership of the land, but common law dedications traditionally convey only easements. ${ }^{20}$ Governments

13. Kratina, 548 P.2d at 1235 ("In Kansas as elsewhere a public roadway may be established in three different ways: by purchase or condemnation, by prescription, or by dedication.”).

14. See U.S. Const. amend. V.

15. See, e.g., Cary v. Pulaski Cty. Fiscal Ct., 420 S.W.3d 500, 515 (Ky. Ct. App. 2013).

16. See, e.g., Danforth v. United States, 308 U.S. 271, 285 (1939) ("A reduction or increase in the value of property may occur by reason of legislation for or the beginning or completion of a project. Such changes in value are incidents of ownership. They cannot be considered as a 'taking' in the constitutional sense.").

17. See, e.g., United States v. Dow, 357 U.S. 17, 22 (1958) ("The usual rule is that if the United States has entered into possession of the property prior to the acquisition of title, it is the former event which constitutes the act of taking."); In re Opening a Private Rd. for Benefit of O’Reilly, 5 A.3d 246, 257 (Pa. 2010) (“'A] physical invasion and permanent occupation of private property, such as that which would be accomplished by the creation of a private road under the Act, is a taking."); Willowmet Homeowners Ass'n v. City of Brentwood, No. M2012-01315-COA-R3CV, 2013 WL 2152522, at*9 (Tenn. Ct. App. May 16, 2013) (“[T]he City's actions in building a public road over Tracts 77 and 86 constitute a taking of the Association's equitable title ....”).

18. See, e.g., Byrnes v. Johnson Cty. Comm'rs, 455 P.3d 693, 698 (Wyo. 2020) (discussing inverse condemnation action as means to claim compensation for road expansion).

19. See generally 26 C.J.S. Dedication $\S 1$ (2020) (defining and describing dedication); 1 Joseph Rasch \& Robert F. Dolan, New York Law \& Practice of Real Property § 20:6 (2d ed. 2020) ("Dedication, in the sense of dedicating property to public use, is the appropriation or donation of land, or of an easement therein, by its owner for the use of the public at large; that is, for use by the public generally rather than by one person or a limited number of persons.").

20. See Мich. Comp. Laws $\S 560.253$ (2020) ("When a plat is certified, signed, acknowledged and recorded as prescribed in this act, every dedication, gift or grant to the public or any person, society or corporation marked or noted as such on the plat shall be deemed sufficient conveyance to vest the fee simple of all parcels of land so marked . . .”); Mazal v. Arias, 143 
often acquire road titles or easements by dedication. ${ }^{21}$ Subdivision or other regulations may require a developer to dedicate roadways as a condition to regulatory approval..$^{22}$ Even if not required, a developer may want to dedicate roadways so that the public, rather than the private owners, will maintain the roads. ${ }^{23}$

To be effective, a dedication of a roadway requires both an indication of intent to dedicate by the landowner and an acceptance of the dedication by the government. ${ }^{24}$ The landowner may expressly indicate intent to dedicate by a deed or other written instrument. ${ }^{25}$ The landowner also may indicate intent to dedicate simply by recording a subdivision plat that designates public roadways. ${ }^{26}$ Until

N.E.3d 1226, 1231 (Ill. App. Ct. 2019) ("It is well-established that a statutory dedication vests title to the dedicated property in the public.”); 2000 Baum Family Tr. v. Babel, 793 N.W.2d 633, 642 (Mich. 2010) ("Common-law dedications do not ordinarily convey the fee. In fact, under the strict rule they never do.” (citation omitted)); Carson City v. Capital City Entm't, Inc., 49 P.3d 632, 63536 (Nev. 2002) ("A statutory dedication operates by way of grant, vesting in the municipality the fee for public use. Under a common-law dedication, however, the fee of land dedicated for a street remains in the owner, subject to a public easement in the land, which is vested in the municipality." (footnotes omitted)); Tinaglia v. Ittzes, 257 N.W.2d 724, 729 (S.D. 1977) ("[T]he easement in question was established through an express, statutory dedication ....”).

21. See, e.g., Hanshaw v. Long Valley Rd. Ass'n, 11 Cal. Rptr. 3d 357, 360 (Ct. App. 2004) (relating developer's offers to dedicate road and referring to developer's testimony that "developers want roads to be public 'because then the public become[s] responsible for the repairs and the maintenance"').

22. See, e.g., 7 Norman Williams, JR. \& John M. TAylor, American Land Planning LAW $\S 166: 7$ (2020) ("It has long been accepted practice to require a subdivision to dedicate land for streets, without cost of the municipality, and there is no serious legal question involved here.").

23. See, e.g., Hanshaw, 11 Cal. Rptr. $3 \mathrm{~d}$ at 360.

24. See, e.g., Kraus v. Dep't of Commerce, 547 N.W.2d 870, 872 (Mich. 1996) ("In cases like these, the well-established rule is that a valid dedication of land for a public purpose requires two elements: a recorded plat designating the areas for public use, evidencing a clear intent by the plat proprietor to dedicate those areas to public use, and acceptance by the proper public authority.”); Camilla Twin Harbor Volunteer Fire Dep’t v. Plemmons, 998 S.W.2d 413, 415 (Tex. App. 1999) ("Implied dedication requires a clear and unequivocal intention on the part of the landowner to appropriate the land to public use, along with an acceptance by the public." (citation omitted)); Restatement (Third) of Prop.: Servitudes $§ 2.18 \mathrm{cmt}$. e (Am. Law Inst. 2000) ("Dedication requires an offer by the owner of the land and an acceptance by the public.").

25. See, e.g., Carlson v. Burkhart, 27 P.3d 27, 32 (Kan. 2001) (“An express dedication is usually accomplished by deed or written instrument."); Tupper v. Dorchester Cty., 487 S.E.2d 187, 192 (S.C. 1997) (noting plat annotation that "we hereby dedicate all streets and easements to the use of the public forever").

26. See, e.g., Kircheimer v. Carrier, 446 S.W.3d 224, 228 (Ky. 2014) (“One method of common-law dedication is dedication by estoppel involving plat, wherein the act of subdividing lots on a plat generally constitutes an offer to dedicate the roads appearing on the plat as public, and the sale of a lot as depicted on the plat completes the dedication." (citation omitted)); Jupe v. City of Schertz, 604 S.W.2d 405, 407 (Tex. Civ. App. 1980) ("The plat filed by Rubin Beck includes a well- 
the government accepts the dedication, the landowner may withdraw the offer of dedication expressly or simply by using the land inconsistently with public ownership. ${ }^{27}$

Some have said that even long use by the public may imply that the landowner intended to dedicate land to the public. ${ }^{28}$ If so, then long use by the public may be the factual basis for either dedication or public prescription. ${ }^{29}$ This makes some sense if prescriptive easements are justified by an implied or "lost" grant; in that case, both doctrines are founded on the landowner's intention to give the public an interest in the land. ${ }^{30}$ But the lost grant theory has been largely abandoned, ${ }^{31}$ making the overlap of these two doctrines somewhat ironic: Dedication results from the landowner's willful conveyance of the land, while modern prescription results from the public's hostile use of the land, adverse to the landowner's title, yet both facts may be proven by long public use. ${ }^{32}$

Inferring intent to dedicate from long use by the public also seems inconsistent with the principle that the party claiming a dedication must prove that the landowner clearly and unequivocally indicated his intention to dedicate the land. ${ }^{33}$ A landowner's inaction in response to long use by the public cannot

defined thirty-foot road easement and the dedicatory language contained on the plat 'dedicates to the use of the public forever, all streets, alleys, ... easements and public places . . .' 'We hold that this shows a clear intent to dedicate the road for public use.").

27. See Kraus, 547 N.W.2d at 876.

28. See Anderson v. Town of Hemingway, 237 S.E.2d 489, 490 (S.C. 1977) ("[Intention to dedicate] also may be implied from long use by the public of the land claimed to be dedicated."); Old Dominion Boat Club v. Alexandria City Council, 749 S.E.2d 321, 326 (Va. 2013) ("Implication of a common law dedication may be found based upon 'long use by the public of the land claimed to be dedicated." (citation omitted)).

29. See infra Part I.C.

30. See, e.g., Kratina v. Bd. of Comm'rs, 548 P.2d 1232, 1235 (Kan. 1976) (discussing lost grant theory).

31. See, e.g., Cedar Beach/Cedar Island Supporters, Inc. v. Gables Real Estate LLC, 145 A.3d 1024, 1030 (Me. 2016) ("Although 'one or two' incidents over a period of time do not establish adversity, a single act of nonacquiescence does interrupt a prescriptive easement claim." (citations omitted)); BRUCE \& ELY, supra note 10, § 5:24 (noting that some courts still require acquiescence, but most courts have abandoned the lost grant theory and the acquiescence element it requires).

32. See generally Clay Alger, Use Interrupted: The Complicated Evolution of Utah's Highway Dedication Doctrine, 2008 UtaH L. REv. 1613, 1614 (2008) ("Despite differing theoretical roots, these two doctrines [dedication and prescription] often overlap, sometimes to the point where it is difficult to distinguish the two.").

33. See, e.g., Carlson v. Burkhart, 27 P.3d 27, 32 (Kan. 2001) (stating that dedication "requires a clear and unequivocal intention on the part of the landowner to provide the land for public use," but holding that long acquiescence in public use and maintenance, combined with testimony suggesting lack of ownership, proved landowner's intention to dedicate); Tinnes v. Brand, 248 S.W.3d 113, 115 (Mo. Ct. App. 2008) ("The landowner's intent to set apart land for public use is the foundation of common law dedication. Such intent must be unequivocally 
unequivocally indicate intention to dedicate the land because inaction could result from other causes, such as unawareness, indifference, neighborly accommodation, lack of resources to take action, and procrastination. ${ }^{34}$

If such evidence is considered in inferring intent to dedicate, allowing long use by the public is a better indicator of intent to dedicate in urban areas than in rural areas. In rural areas, allowing the public to use a roadway is especially unclear and equivocal, because such use often does not interfere with the landowner's use of the land. As the Supreme Court of Virginia explained:

[W] hat may amount to a dedication in an urban area will not serve the same purpose in a rural one. This is because landowners in rural areas frequently allowed roads to be opened through their property without intending a dedication to the public. Just as important, the government might not have any intention to accept the road and be responsible for its maintenance. Thus, before a rural road can be dedicated, there must be a formal acceptance by the public..$^{35}$

Recognizing such concerns in rural areas, the Texas Legislature passed a law in 1981 stating that in counties of 50,000 people or less, a dedication must be explicit and communicated in writing to the county commissioners. ${ }^{36}$ Such a reform would certainly better protect rural landowners from unintentionally dedicating public roads, but apparently other states have not followed Texas's example.

In order for the dedication to be effective, the government generally must also

manifested, expressly or by plain implication." (citations omitted)); Heller v. Gremaux, 53 P.3d 1259, 1265 (Mont. 2002) ("The intent of an offer to dedicate must be clear, satisfactory, and unequivocal."); Anderson, 237 S.E.2d at 490 (“Absent an express gift, one who asserts a dedication must demonstrate conduct on the part of the landowner clearly, convincingly and unequivocally indicating his intention to create a right in the public." (citation omitted)); Jackson v. Byrn, 393 S.W.2d 137, 140 (Tenn. 1965) (requiring clear and unequivocal evidence of intention to dedicate).

34. See Tinnes, 248 S.W.3d at 116 (observing that evidence indicated owner accepted public use of a private road because owner wanted people to access owner's resort, not because of intent to dedicate the road to the public); Heller, 53 P.3d at 1264-65 (concluding that landowners did not unequivocally indicate intention to dedicate a road, but rather allowed for its use as a neighborly accommodation); Barstow v. State, 742 S.W.2d 495, 506 (Tex. App. 1987) (“As a general rule, the owner's donative intention may not be inferred from evidence that shows only that the public used the roadway for a long period of time without protest or dispute by the owner. The rationale for this general rule is that such evidence, standing alone, remains equivocal on the issue of the owner's intention. The public's use of the way and the owner's inaction or acquiescence may, with equal likelihood, indicate either a permissive use by the public, as under a revocable license, or an intention on the owner's part to set the way apart irrevocably for public use. Neither conclusion is more likely than the other under such evidence, standing alone." (citation omitted)).

35. Bradford v. Nature Conservancy, 294 S.E.2d 866, 875 (Va. 1982) (citations omitted); accord Mulford v. Walnut Hill Farm Grp., LLC, 712 S.E.2d 468, 473 (Va. 2011).

36. Tex. Transp. Code Ann. $\S \S 281.001, .003$ (West 2020); see also Mitchell v. Ballard, 420 S.W.3d 122, 130 (Tex. App. 2012). 
accept the dedication. ${ }^{37}$ Some jurisdictions allow the government to accept at any time as long as the offer to dedicate hasn't been revoked. ${ }^{38}$ Others say the offer must be accepted within a reasonable time under the circumstances. ${ }^{39}$

One explanation for the acceptance requirement is that, without it, a private landowner could give the public responsibility for a road that the public doesn't want or need. ${ }^{40}$ This is a good reason for requiring acceptance if merely acquiring an easement or title to a roadway establishes a public road and gives the public the responsibility to maintain it. ${ }^{41}$ However, if state law distinguishes between acquiring a property interest and establishing a road, and requires distinct actions for each, then merely receiving a dedicated property interest doesn't impose such

37. See, e.g., IDAHO CODE $\S 50-1309$ (2) (2020) ("No dedication or transfer of a private road to the public can be made without the specific approval of the appropriate public highway agency accepting such private road."); Carlson, 27 P.3d at 32 (“The party asserting that a roadway has been dedicated for public use bears the burden of proof and must show: (1) an intent by the property owner to dedicate the land for such use; and (2) acceptance by the public." (citation omitted)); Hanscom v. Bitler, 883 A.2d 1111, 1114 (Pa. Commw. Ct. 2005) (“Although a developer may propose public dedication of a street ...., the Ordinance does not obligate the Township to accept dedication of a road or street, and any street not accepted and maintained as a public street is classified as a private street."); Prudential Tr. Co. v. City of Laramie, 492 P.2d 971, 973 (Wyo. 1972) ("It is apparent, therefore, that dedications made subsequent to the amendments of 1943 and 1965 are by statute not effective until the plat is approved and accepted by the appropriate authority.").

38. See, e.g., J \& A Cantore, LP v. Vill. of Villa Park, 79 N.E.3d 800, 819 (Ill. App. Ct. 2017) ("[A]n acceptance is timely if it is made before an offer to dedicate has been formally withdrawn or revoked by the dedicator." (citation omitted)); Town of Lake George v. Landry, 946 N.Y.S.2d 704, 706 n.3 (App. Div. 2012) ("Plaintiff's delay in accepting the dedication — although admittedly significant - is not fatal, as the mere 'lapse of time does not extinguish an offer of dedication, which may be accepted at any time prior to a valid revocation by all interested parties."').

39. See Katz v. Town of West Hartford, 469 A.2d 410, 413 (Conn. 1983) (“'A]n acceptance must occur within a reasonable period of time after the intent to dedicate the property has been manifested." (citation omitted)); Republic Bank of Chi. v. Vill. of Manhattan, 32 N.E.3d 1141, 1148 (Ill. App. Ct. 2015) ("It is well settled that acceptance is timely if made before the offer to dedicate has been formally withdrawn or revoked by the dedicator." (citations omitted)).

40. See, e.g., Cary v. Pulaski Cty. Fiscal Ct., 420 S.W.3d 500, 508 (Ky. Ct. App. 2013) (" $[\mathrm{T}]$ here is a valid public policy behind requiring a fiscal court to evidence its acceptance of a particular road by way of an official order: A county should not be held responsible for maintenance of a road which happens to become public through a process over which it has no control." (citation omitted)); Kraus v. Mich. Dep't of Commerce, 547 N.W.2d 870, 873 (Mich. 1996); Hersh v. Plonski, 938 A.2d 98, 102 (N.H. 2007); cf. N.M. STAT. ANN. § 67-2-2 (2020) (“All public highways, except such as are owned and operated by private corporations, . . . shall be maintained and kept in repair by the respective counties in which they are located.").

41. See, e.g., State ex rel. Fitzthum v. Turinsky, 174 N.E.2d 240, 243 (Ohio 1961) (“[T]o constitute an acceptance of land dedicated for street or road purposes mere user by the public, without an acceptance by responsible public authorities, is not sufficient to charge those authorities with the duty of maintenance."). 
a burden on the government. ${ }^{42}$

Even if so, another reason for requiring acceptance of a dedication is to prevent the land from being unused altogether, with landowners thinking they passed it on to the government and the government not doing anything with it. ${ }^{43}$ Therefore, regardless of the consequences of accepting dedication, courts should require evidence that the government has decided that it is in the public interest to accept the dedication of a roadway.

The government may expressly accept a dedication by a resolution or other formal action. ${ }^{44}$ Some state road dedication statutes require express acceptance by resolution of the governing authority. ${ }^{45}$ This is the better rule and practice because otherwise the status of a road may be unclear to government and private owners alike. But many states don't require express acceptance. ${ }^{46}$ In fact, when the offer of dedication is express pursuant to a statute, some states don't require the government to do anything to accept the dedication; properly filing a subdivision plat alone completes the dedication. ${ }^{47}$ In Alabama, plat road

42. See infra Part II.

43. See Kraus, 547 N.W.2d at 873.

44. See, e.g., J \& A Cantore, LP v. Vill. of Villa Park, 79 N.E.3d 800, 818 (Ill. App. Ct. 2017) ("An express acceptance can be shown by a direct municipal action, such as the passing and recording of an order, resolution, or other action accepting the dedication ....").

45. See, e.g., Haw. Rev. Stat. § 264-1(c)(1) (2020); Ky. Rev. Stat. Ann. § 178.010(1)(b) (West 2020) (requiring express acceptance of county road); id. $\S 82.400$ (1) (requiring municipal acceptance of dedication); OHIO Rev. CODE ANN. § 723.03 (West 2020) ("A street or alley, dedicated to public use by the proprietor of ground in any municipal corporation, shall not be a public street or alley, or under the care or control of the legislative authority of such municipal corporation, unless the dedication is accepted and confirmed by an ordinance specially passed for such purpose.”); Maui Ranch Estates Owners Ass'n v. Cty. of Maui, 724 P.2d 118, 124 (Haw. Ct. App. 1986) (holding that county's maintenance and inclusion of a road in county road index did not amount to acceptance of dedication because the statute only allowed a county council to accept dedication "through ordinance or resolution or by voting on a motion made at a council meeting" (citation omitted)); Ellington v. Becraft, 534 S.W.3d 785, 790 (Ky. 2017); Cary, 420 S.W.3d at 507-08 ("However, the Fiscal Court's ultimate decision to adopt a given road as a county road - and thus assert control and possession of it — must be evidenced by proof consisting of an official order, resolution or ordinance of the fiscal court that appears of record. This point was underscored in Illinois Cent. R. Co. v. Hopkins County, 369 S.W.2d 116 (Ky. 1963), in which the Court held that a road was not a 'county road,' even in the face of several years' worth of county maintenance and a substantial passage of time, in the absence of a formal order of the fiscal court accepting the road into its system of maintenance.").

46. See, e.g., Kraus, 547 N.W.2d at 872-73 ("Public acceptance must be timely and must be disclosed through a manifest act by the public authority 'either formally confirming or accepting the dedication, and ordering the opening of such street, or by exercising authority over it, in some of the ordinary ways of improvement or regulation."' (citations omitted)).

47. 1 James A. Kushner, Subdivision Law and Growth Management § 6:16 (2d ed. 2015) ("Under some state statutes or common law, no formal acceptance is required as the dedication is finalized on the filing of the plat and compliance with conditions."). 
dedications to counties do not require acceptance, while dedications to incorporated municipalities do. ${ }^{48}$ This statutory difference means that rural areas are more likely to have roadways dedicated to the public that aren't wanted, developed, maintained, or even recognized by the county government. ${ }^{49}$

Despite the public and private benefits of express acceptance, most states don't require it. ${ }^{50}$ The government instead may implicitly accept a dedication by improving, regulating, or even not taxing the road. ${ }^{51}$ Some state statutes declare that such actions accept dedications. ${ }^{52}$ Some state dedication statutes require express acceptance, but courts construe these dedication statutes to not abrogate dedication under the common law, which generally recognizes implied acceptance by conduct. ${ }^{53}$ At least a couple of state dedication statutes apply only to municipalities, leading courts to conclude that counties can only receive dedications of roadways by common law dedication. ${ }^{54}$

48. See Harper v. Coats, 988 So. 2d 501, 507 (Ala. 2008) (interpreting and applying state statutes to hold that governmental acceptance of dedication was necessary for roads within city limits, but not subdivision plat dedications of roads outside those limits).

49. Cf. Chalkley v. Tuscaloosa Cty. Comm'n, 34 So. 3d 667, 673 n.3 (Ala. 2009) (noting that even though roads in county subdivision may be dedicated without acceptance, court's decisions had not changed rule that "the ministerial function of a city or county engineer in approving a plat cannot 'bind the city [or county] to maintain such streets' or other portions of the plat dedicated to the public" (citation omitted)).

50. See, e.g., Kraus, 547 N.W.2d at 872-73.

51. See, e.g., Meshberg v. Bridgeport City Tr. Co., 429 A.2d 865, 869-70 (Conn. 1980) ("Where a municipality grades and paves a street, maintains and improves it, removes snow from it, or installs storm or sanitary sewers, lighting, curbs, or sidewalks upon it there exists a factual basis for finding an implied acceptance of the street by the municipality.”); Carlson v. Burkhart, 27 P.3d 27, 33 (Kan. 2001) ("Maintenance or improvement by a municipality or county can support a finding of implied acceptance of the road."); McBroom v. Jackson Cty., 154 So. 3d 827, 837 (Miss. 2014) ("[A]cceptance can be manifested by failure to assess taxes on a street." (citation omitted)); Favre v. Jourdan River Estates, 148 So. 3d 361, 373-74 (Miss. 2014) ("Hancock County accepted the offer for dedication by way of its actions. . . . The county's paving of the road is sufficient evidence that the county controlled the road and repaired it on the assumption the road was public.”); Tupper v. Dorchester Cty., 487 S.E.2d 187, 192 (S.C. 1997).

52. See, e.g., MinN. StAT. § 160.05(1)(a) (2020) ("When any road ... has been used and kept in repair and worked for at least six years continuously as a public highway by a road authority, it shall be deemed dedicated to the public to the width of the actual use and be and remain, until lawfully vacated, a public highway whether it has ever been established as a public highway or not.").

53. See, e.g., Poznic v. Porter Cty. Dev. Corp., 779 N.E.2d 1185, 1192 (Ind. Ct. App. 2002) ("“A defective statutory dedication may operate as a common-law dedication, and a valid commonlaw dedication will prevail over an invalid statutory dedication."' (citation omitted)).

54. See Colo. Rev. Stat. § 31-23-107 (2020); Miss. Code Ann. § 21-19-63 (2020); Turnbaugh v. Chapman, 68 P.3d 570, 572 (Colo. App. 2003) ("Dedication of land to a county may be accomplished only through common law dedication because Colorado statutory procedures apply only to cities and towns."); McBroom, 154 So. 3d at 834 ("[W]hile statutory dedication and 
One explanation for inferring acceptance from such actions is that a government surely would not spend public money to maintain a private road, so the government must have intended the road to be public. ${ }^{55}$ While it may be true that the government would not spend public money to maintain a private road, the decision to spend public money to maintain a private road is not good evidence of a decision to accept a dedication. It only indicates that the county thinks it is a public road and recognizes its responsibility to maintain such roads. Especially in rural areas, county roads may have an unclear status and history. If the road is used by the public or thought to be public, the county may maintain or regulate it not because it has decided it is in the public interest to have such a road, but because it mistakenly believes it already is a public road. ${ }^{56}$

Furthermore, the county officials deciding to maintain a road often will not be the same officials who have the authority to accept the dedication of a roadway. ${ }^{57}$ If such actions are sufficient to accept a dedication, some roads may become public without the public entity's authorized officials ever directly deciding the question of whether it is in the public interest to accept the dedication. Virginia courts seem to have recognized these concerns, holding that, while "acceptance may be implied in urban areas, a formal acceptance or express assertion of dominion over the road by public authority is required before dedication of a rural road is complete." ${ }^{.58}$

Some courts say that dedication can be implicitly accepted not just by the government's conduct, but by long public use generally. ${ }^{59}$ If state law doesn't

acceptance are limited by plain statutory language to municipalities, the common law of dedication and acceptance can be applied more broadly to actions by counties.").

55. See Carlson, 27 P.3d at 33 ("Indeed, governmental entities are not likely to devote public money to private roads.” (citation omitted)); Tex. Op. Att'y Gen. No. JC-0172, 2000 WL 52830, at *1 (Jan. 24, 2000) ("Aside from the narrow authority granted by . . . the Texas Constitution, counties are not constitutionally or statutorily authorized to construct or maintain private roads."). But see Tomchak v. Walker, 700 P.2d 68, 70 (Idaho 1985) ("We are aware that in some counties it is a 'common custom' for county road crews to gratuitously aid or to contract with rural citizens in the maintenance of private roadways.").

56. Cf. Chambers Cty. v. Frost, 356 S.W.2d 470, 474 (Tex. Civ. App. 1962) (recounting county engineer's testimony that "he would not have caused the work to have been done had he not believed that these roads were public roads").

57. See Meshberg v. Bridgeport City Tr. Co., 429 A.2d 865, 870 (Conn. 1980) (observing that plans of study committees could not support a finding of acceptance because evidence did not indicate that those studies were "conducted by town officials with the authority to accept the street on behalf of the municipality").

58. Burks Bros. of Va., Inc. v. Jones, 349 S.E.2d 134, 141 (Va. 1986) (citation omitted).

59. See, e.g., Biagini v. Beckham, 78 Cal. Rptr. 3d 171, 178 (Ct. App. 2008); Katz v. Town of West Hartford, 469 A.2d 410, 412 (Conn. 1983) ("Implied acceptance may be established either by the public's actual use of the property or by actions of the municipality." (citation omitted)); Henly v. Cty. of Chisago, 370 N.W.2d 920, 923 (Minn. Ct. App. 1985) ("Public acceptance can be shown by public travel on the dedicated road or by acts of public officials in improving and maintaining the road." (citations omitted)); City of Louisville v. Hull, 292 So. 2d 177, 179 (Miss. 
distinguish between accepting a dedication and creating a public road, public use should not establish acceptance of dedication. The government, on behalf of the broader public, should not be burdened by the obligation to maintain a roadway just because some part of the public has used the road for a long time. ${ }^{60}$ That subset of the public does not have the authority to impose such an obligation on the entire tax-paying population. Rather, the government should bear the responsibility to maintain a road only if the government itself manifested acceptance of that obligation. ${ }^{61}$ The public's use of a roadway is not at all evidence that the government has decided it is in the public interest to accept ownership of and responsibility for a road.

This is especially true in rural areas where the public's use of the road may not be intensive, even though it may be typical for a public road in such an area and thus sufficient to manifest public acceptance. ${ }^{62}$ As one court cautioned, allowing public use to establish government acceptance "might well subject township trustees to the responsibility of improving and maintaining many of the country lanes leading only to a single farmhouse merely because deliverymen, mailmen and other segments of the public have been using that lane for a period of years." ${ }^{\circ 3}$

Some have suggested that public use is sufficient acceptance because the

1974) ("An implied dedication results only from long use for a specific public purpose, the discontinuance of which would constitute a violation of good faith to the public and to those who have acquired private property with a view to the use contemplated by the dedication.").

60. See Hanshaw v. Long Valley Rd. Ass'n, 11 Cal. Rptr. 3d 357, 364 (Ct. App. 2004) (distinguishing between acceptance by the county and acceptance of a road by public use, which creates a public road, but "does not cast any maintenance or liability burden on the County"); McGarry v. Scott, 72 P.3d 608, 615-16 (N.M. 2003).

61. See Ellington v. Becraft, 534 S.W.3d 785, 790-92 (Ky. 2017) (distinguishing county roads from public roads without county acceptance); Kraft v. Town of Mt. Olive, 645 S.E.2d 132, 137 (N.C. Ct. App. 2007) (“An implicit dedication occurs when: (1) 'the dedicated property is used by the general public'; and (2) 'coupled with control of the road by public authorities for a period of twenty years or more.' To be clear, it is not enough for the public to use the alley for twenty years, but the 'public authorities must assert control over [the alley]." (citations omitted)); Bumgarner v. Reneau, 413 S.E.2d 565, 568 (N.C. Ct. App. 1992) ("A dedication of a road to the general public is a revocable offer until it is accepted on the part of the public in 'some recognized legal manner' and by a proper public authority. A 'proper public authority' is a governing body having jurisdiction over the location of the dedicated property, such as a municipality, an incorporated town, a county, or any public body having the power to exercise eminent domain over the dedicated property." (citations omitted)); State ex rel. Fitzthum v. Turinsky, 174 N.E.2d 240, 243 (Ohio 1961) (“" [T]o constitute an acceptance of land dedicated for street or road purposes mere user by the public, without an acceptance by responsible public authorities, is not sufficient to charge those authorities with the duty of maintenance.").

62. See Bradford v. Nature Conservancy, 294 S.E.2d 866, 875 (Va. 1982) (see supra text accompanying note 35$)$.

63. Fitzthum, 174 N.E.2d at 243. 
public may have come to rely upon the dedication. ${ }^{64}$ The common law dedication theory has been described as estopping the owner from denying the dedication because of public reliance during a long period of public use, rather than as an implied grant. ${ }^{65}$ However, while the public's reliance may estop the owner from denying the dedication, resulting in a public easement, that doesn't mean it should estop the government from denying the dedication. If the government hasn't done anything to manifest acceptance of the dedication, it has done nothing upon which the public could rely. The public has no reason to rely on the government maintaining the road if it never has. The public's reliance on the owner's acquiescence justifies only a finding of a public easement to continue use of the roadway, which prevents the owner from interfering with its use; such a finding does not justify going further and holding that the government has accepted the dedication and the responsibility to maintain the road. ${ }^{66}$

\section{Prescription}

In most states, the government also may acquire an easement for a roadway by prescriptive use. ${ }^{67}$ Acquiring a public easement by prescription generally requires that the public has used the roadway openly, continuously without interruption, and under a claim of right for the state's relevant limitations period, ${ }^{68}$ or in some states, for a different period of time specified in the statute. ${ }^{69}$

64. See, e.g., Hull, 292 So. 2 d at 179 (see supra note 59).

65. See, e.g., 23 AM. Jur. 2D Dedication $§ 54$ (2020) (“A common law dedication does not operate as a grant but as an equitable estoppel.”).

66. $C f$. McGarry v. Scott, 72 P.3d 608, 615-16 (N.M. 2003) (explaining that public use may result in a public easement, but not an acceptance of a roadway that obligates the government to maintain the roadway). The Supreme Court of Virginia has held that the public cannot acquire a prescriptive easement over a road. See Dykes v. Friends of C.C.C. Rd., 720 S.E.2d 537, 542 (Va. 2012). The Kansas Supreme Court held that long public use did not create a prescriptive easement because otherwise the government would unwillingly have the duty to maintain the road, but did not directly address the possibility that the public could have an easement over a roadway that was not a county road. See Kratina v. Bd. of Comm'rs, 548 P.2d 1232, 1238 (Kan. 1976).

67. See BRUCE \& Ely, supra note 10, $\S 5: 25$ ("[T] he trend of modern cases is to recognize that the public may acquire prescriptive easements."). But see State ex rel. Miller v. Dawson, 858 P.2d 1213, 1215 (Ariz. 1993) (holding that neither Arizona common law nor statute permits the acquisition of public highways by prescription); Friends of the Trails v. Blasius, 93 Cal. Rptr. 2d 193, 199 (Ct. App. 2000) ("Doctrinal impediments have barred the application of the common law of prescription to justify the acquisition of a public easement. For this reason in California it is said that '[a] public easement arises only by dedication."' (citations omitted)); Kirkland v. Kolodziej, 128 A.3d 407, 421 (Vt. 2015) ("[W]e conclude that the state of our law is that a nonpublic road cannot become public through a prescriptive easement . ..."); Dykes, 720 S.E.2d at 542 (holding that public may acquire a road by dedication, but not by prescription).

68. See, e.g., Key v. Allison, 70 So. 3d 277, 281 (Ala. 2010); Bd. of Cty. Comm'rs v. Flickinger, 687 P.2d 975, 980-81 (Colo. 1984) (holding that public acquired road by prescriptive use); Kratina, 548 P.2d at 1235; Heller v. Gremaux, 53 P.3d 1259, 1263 (Mont. 2002); Teadtke v. 
Some state statutes say that a specified period of use creates a public road by prescription, without reciting all of the common law elements. ${ }^{70}$ However, courts generally construe such statutes to be codifications of the common law and require the same elements anyway. ${ }^{71}$

Havranek, 777 N.W.2d 810, 819 (Neb. 2010).

69. See Alaska Stat. § 09.45.052 (2020) (specifying a seven-year period for "[t]he uninterrupted adverse notorious possession of real property under color and claim of title" and a tenyear period for adverse use of private land as a public road); COLO. REV. STAT. §§ 38-41-101, 43-2201 (2020) (specifying eighteen-year limitation period for adverse possession generally, but twentyyear period for public highways); GA. CODE ANN. § 32-3-3(c) (2020) ("Notwithstanding Code Section 44-5-163 [specifying a twenty-year prescriptive period], any state agency, county, or municipality is authorized to acquire by prescription and to incorporate into its system of public roads any road on private land which has come to be a public road by the exercise of unlimited public use for the preceding seven years or more.”); IDAHO CODE $\S \S 5-207,-210$ (2020) (requiring twenty years for adverse possession generally, but five years of use and public maintenance for public roads); Мich. COMP. LAwS $\S 221.20$ (2020) ("[A]ll roads that shall have been used as such for 10 years or more, whether any record or other proof exists that they were ever established as highways or not, and all roads which have been or which may hereafter be laid out and not recorded, and which shall have been used 8 years or more, shall be deemed public highways . ...").

70. See, e.g., 605 ILl. COMP. STAT. 5/2-202 (2020) ("Highway-any public way for vehicular travel which has been ... used by the public as a highway for 15 years . ..."); MicH. COMP. LAws $\S 221.20$ ("[A]ll roads that shall have been used as such for 10 years or more, whether any record or other proof exists that they were ever established as highways or not, and all roads which have been or which may hereafter be laid out and not recorded, and which shall have been used 8 years or more, shall be deemed public highways . . . ."); N.H. ReV. Stat. AnN. § 229:1 (2020) ("Highways [include] . . roads which have been used as such for public travel . . f for 20 years prior to January 1, 1968 . . ..”); N.D. CENT. CoDE § 24-07-01 (2020) (“All public roads and highways within this state which have been or which shall be open and in use as such, during twenty successive years, hereby are declared to be public roads or highways and confirmed and established as such whether the same have been laid out, established, and opened lawfully or not."); WASH. REV. CODE $§ 36.75 .080$ (2020) ("All public highways in this state, outside incorporated cities and towns and not designated as state highways which have been used as public highways for a period of not less than ten years are county roads ....").

71. See, e.g., McIntyre v. Bd. of Cty. Comm'rs, 86 P.3d 402, 406 (Colo. 2004); Flickinger, 687 P.2d at 980 ("Section 43-2-201(1)(c) . . . states in pertinent part that 'all roads over private lands that have been used adversely without interruption or objection on the part of the owners of such lands for twenty consecutive years' are declared to be public highways. This provision codifies the common law method by which the public can obtain title to roadways by adverse use. A party seeking to establish a road across private property as a public highway must demonstrate the following: (1) members of the public must have used the road under a claim of right and in a manner adverse to the landowner's property interest; (2) the public must have used the road without interruption for the statutory period of twenty years; and (3) the landowner must have had actual or implied knowledge of the public's use of the road and made no objection to such use." (citations omitted)); Feldker v. Crook, 567 N.E.2d 1115, 1123 (Ill. App. Ct. 1991) (applying state statute that any road "used by the public as a highway for 15 years" is a public highway and stating that the 
Whether use of a lightly used rural road is public at all may be an especially challenging question. If a rural road doesn't lead to a recreational area or connect more frequently used locations and roads, only a few landowners may regularly use the road to access their properties. From the public's perspective, the use may seem to be just what one would expect of a public road in such a location. But landowners may fairly object that they wouldn't have reasonably perceived the use by a small group of neighbors as manifesting a public use rather than a

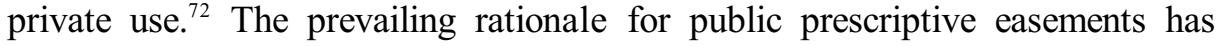

"requirements necessary to establish a public highway by prescription under the statute are the same as those necessary to establish a private easement by prescription" (citations omitted)); Pine Bluffs Area Prop. Owners Ass'n v. DeWitt Landing Ass'n, 792 N.W.2d 18, 36 (Mich. Ct. App. 2010) (reaffirming that, although statute expressly requires only 10 years of use to establish a road as a public highway, the claimant must prove "“(1) a defined line, (2) that the road was used and worked on by public authorities, (3) public travel and use for ten consecutive years without interruption, and (4) open, notorious, and exclusive public use"' (footnote and citation omitted)); Blagbrough v. Town of Wilton, 755 A.2d 1141, 1144 (N.H. 2000) ("We have construed the 'public use' provision of RSA 229:1 as describing the establishment of a public highway through prescription."); McKenzie Cty. v. Reichman, 812 N.W.2d 332, 337 (N.D. 2012) (applying state statute expressly requiring only that a road be "open and in use" for 20 years to be a public road, N.D. CENT. CODE $§ 24-07-01$ (2020), and stating that "[a] party claiming a road by prescription under N.D.C.C. $\S$ 24-07-01, must establish by clear and convincing evidence the general, continuous, uninterrupted and adverse use of the road by the public under a claim of right for 20 years" (citations omitted)); Primark, Inc. v. Burien Gardens Assocs., 823 P.2d 1116, 1117, 1121 (Wash. Ct. App. 1992) (stating that "[i]n order to establish a highway by prescription, the public use of the way must be general, adverse, uninterrupted and continuous for a period of 10 years under a claim of right" even though statute, WASH. REV. CODE $§ 36.75 .080$ (2020), says only that "[a]ll public highways in this state, outside incorporated cities and towns ... which have been used as public highways for a period of not less than ten years are county roads"). But see Fenley Farms, Inc. v. Clark, 404 N.E.2d 1164, 1168-69 (Ind. Ct. App. 1980) ("Under the [former] statute but one question is presented, and that is, Has the road been used as a highway for twenty years? . . . If it has, the statute fixes its status as a highway, and it is wholly immaterial whether the use has been with the consent, or over the objection of the landowner . . It is not a question of a common-law dedication, or a way strictly by prescription, though analogous to the latter. . . . It is a statutory highway, by twenty years' user, irrespective of all other methods of creating highways." (quoting Pitser v. McCreery, 88 N.E. 303, 306 (Ind. 1909))).

72. See Ellington v. Becraft, 534 S.W.3d 785, 798 (Ky. 2017) ("The use of this passage was only for the purpose of reaching the Ellington property; it was hardly a necessary passage for the community at large. Instead, it was limited to those few members of the public (rather than the general public at large) using the path to reach the homes located along what was known as Smokey Hollow Road. This is insufficient as a matter of law to constitute actual use by the public to create a public road.”); Rominger v. City Realty Co., 324 S.W.2d 806, 808 (Ky. Ct. App. 1959) (“[O]ne of the essentials of the establishment of a road by prescription is the use of the land in question by the public and such use must be by the public generally as a way common to all; the mere use by a few individuals, from time to time, as distinguished from the public generally, does not constitute such use as creates title in the public by prescription."). 
shifted from an implied dedication by the landowner to a right acquired by long use, rather than by implied grant. ${ }^{73}$ Focusing on the public's conduct in acquiring rights might make courts more likely to accept light use by a small group as a public use if the road has been used as one would expect a public road to be used in such circumstances. ${ }^{74}$ But the principle and elements of public prescriptive easements still require that the owner reasonably should have known about the objectively asserted public right. ${ }^{75}$ Therefore, courts should determine whether the use is public not just by considering whether the use is the kind one would expect of a public road in the location, but by considering whether a reasonable landowner in the situation would have perceived the use as public.

The requirement that use be open or notorious ensures that landowners reasonably should have known about the claimed public right to use a road over the landowners' property. ${ }^{76}$ If the landowners don't actually know about the use, the use must be sufficiently visible and frequent that the landowners would have known the public was using it if they kept themselves informed about the condition of their property. ${ }^{77}$ Consequently, rare use or use by just one or a few

73. See Restatement (Third) of Prop.: Servitudes $\S 2.18 \mathrm{cmt}$ f (Am. Law Inst. 2000); id. $\S 2.17 \mathrm{cmt}$. c ("Prescription doctrine rewards the long-time user of property . . . In its positive aspect, the rationale for prescription is that it rewards the person who has made productive use of the land, it fulfills expectations fostered by long use, and it conforms titles to actual use of the property.").

74. See, e.g., Villadsen v. Mason Cty. Rd. Comm'n, 706 N.W.2d 897, 905 (Mich. Ct. App. 2005) ("Although ... the number of people who traversed the road was not high, the law does not fix the number of people who must travel upon a road to satisfy this element. We hold that the portion of Darr Road in dispute was traveled as much as the circumstances of the surrounding population, and their business, required." (citations omitted)).

75. See, e.g., Town of Dunbarton v. Guiney, 236 A.3d 860, 866 (N.H. 2020) ("Further, Town employees incidentally plowing a small piece of property for the purpose of reaching a safe place to turn around is not the sort of public use that is 'calculated to apprise the owner that it was had under a claim of right.' A reasonable person would not understand the Town to be making a claim of right to their property by such conduct." (quoting Wason v. Nashua, 155 A. 681, 685 (N.H. 1931))); Restatement (Third) of Prop.: Servitudes $§ 2.18$ cmt. c (Am. Law Inst. 2000) (“A similar result should follow if use by the wider public would substantially exceed what the owner of the property should reasonably have expected would become authorized by the owner's failure to halt the adverse use in time to prevent the establishment of prescriptive rights.").

76. See, e.g., Bd. of Cty. Comm'rs v. Ogburn, 554 P.2d 700, 701 (Colo. App. 1976) (“[I]n order to establish a public highway by means of adverse user, a road must have been adversely used in an uninterrupted fashion by the public under a claim of right for the applicable period of limitations with the actual or implied knowledge of the landowner across whose property the roadway runs." (citation omitted)).

77. See, e.g., Breiner v. Holt Cty., 581 N.W.2d 89, 96 (Neb. Ct. App. 1998); Restatement (Third) of Prop.: Servitudes $\S 2.17 \mathrm{cmt}$. h (AM. LAW InSt. 2000) (“The purpose of the requirement that the use be open or notorious is to give the owner of the servient estate ample opportunity to protect against the establishment of prescriptive rights. To satisfy this requirement, the adverse use must be made in such a way that a reasonably diligent owner would learn of its 
people generally would not create a public easement by prescription. ${ }^{78}$ However, even if the use is rare, if other visible conditions indicate that a road is viewed as public, such indications may make the use sufficiently open. ${ }^{79}$ For example, a Nebraska court held that even though trail roads were traveled infrequently and sporadically, the infrequent use combined with trees and some fences along the road made the prescriptive use sufficiently visible. ${ }^{80}$

The public use also must be continuous and uninterrupted. ${ }^{81}$ Continuous and uninterrupted use doesn't mean someone was always using the road, only that it was used as needed or appropriate without effective interruption by the landowner. ${ }^{82}$ In fact, even ineffective attempts to interrupt public use may prevent a prescriptive easement in minority states where courts still require acquiescence by the landowner, despite the general judicial abandonment of the lost grant theory of prescriptive easements. ${ }^{83}$ Rural landowners might use a gate to block a road and assert their right to exclude. ${ }^{84}$ If they lock the gate and effectively prevent use of the road, the public will not acquire a prescriptive easement in any state. ${ }^{85}$ But if the gate is left open or unlocked, the presence of the gate itself does not interrupt the public's use. ${ }^{86}$ Even if the gate is locked rarely and briefly, the public use might still be sufficiently continuous and uninterrupted. ${ }^{87}$ As one court reasoned, even though the landowner claimed to have blocked the road once a

existence, nature, and extent.").

78. See, e.g., Ada Cty. Highway Dist. v. Total Success Invs., LLC, 179 P.3d 323, 328 (Idaho 2008) ("Public status of the roadway can be established by proof of regular maintenance and extensive public use. . . ' [T] he primary factual questions are the frequency, nature and quality of the public's use and maintenance.' The public must use the road regularly, and the use must be more than only casual or desultory." (citations omitted)); Leisz v. Avista Corp., 174 P.3d 481, 490 (Mont. 2007) (affirming holding that occasional use of access road was insufficient to establish prescriptive easement).

79. See, e.g., Breiner, 581 N.W.2d at 94-95 (holding that rarely used trail roads were public roads by prescription where owner had placed trees and some fences along the road to separate it from the rest of his private property).

80. Id. at 94. ("Considering the road is in an isolated ranching area, the infrequency and sporadic nature of travel upon it is not controlling.").

81. See Restatement (Third) of Prop.: Servitudes $\S 2.17(2)$ (Am. Law Inst. 2000).

82. See id. § 2.17 cmts. i-j; Breiner, 581 N.W.2d at 94.

83. See supra note 31 .

84. See, e.g., Jackson v. Bd. of Comm'rs, 916 N.E.2d 696, 704 (Ind. Ct. App. 2009).

85. See, e.g., id. ("When the use of a highway is interrupted by the use of gates or bars, which evidences the intention of the owner to exclude the public from its uninterrupted use, the prescriptive right is destroyed . . . "’ (quoting Mich. Cent. R.R. Co. v. Michigan City, 169 N.E. 873, 877 (Ind. Ct. App. 1930))).

86. See Kostbade v. Metier, 432 P.2d 382, 385 (Mont. 1967) ("The . . gate did not preclude the public from using the road as it was left unlocked. During the greater part of the year this gate was left open and there is also testimony that the public opened it and passed through during the times that it was closed."); Breiner, 581 N.W.2d at 94.

87. See King v. Corsini, 335 N.E.2d 561, 565 (Ill. App. Ct. 1975). 
year, "the law requires that the claimant of the right of way acquiesce in the interruption in such manner as to make the subsequent use merely permissive. By obstructing a highway, an individual cannot divest the public of its right to traverse unless the obstruction is submitted to for such a period of time as to raise a fair presumption of abandonment." 88

A use is commonly presumed to be under a claim of right, or adverse, whenever the other common law requirements are met. ${ }^{89}$ In general, this requirement for a prescriptive easement simply means that the use is inconsistent with the landowner's rights, without depending upon permission or agreement from the landowner. ${ }^{90}$ While lighter use may be sufficient to satisfy the other requirements in a rural area, thus suggesting that rural owners must be especially vigilant to prevent unwanted prescriptive easements, such use of a rural road is likely not hostile to the landowner's actual interests. Appropriate use of a private rural road is legally inconsistent with the owner's right to exclude, but likely does no harm and is not worth making efforts to prevent. ${ }^{91}$ Furthermore, the public benefits from enjoying the access the private road provides. ${ }^{92}$ Therefore, presuming that public use of an open private rural road is by virtue of the owner's implied permission, rather than presuming it is adverse, is more consistent with the probable facts and the public interest, avoiding unnecessary litigation or restrictions on public use of private rural roads.

Courts generally do presume that use of a rural roadway is permissive if the land is undeveloped and unenclosed. ${ }^{93}$ But common expressions of the

88. Id. (citation omitted).

89. See, e.g., Albany \& E. R.R. Co. v. Martell, 469 P.3d 748, 751 (Or. 2020); Teadtke v. Havranek, 777 N.W.2d 810, 819 (Neb. 2010) ("The prevailing rule is that where a claimant has shown open, visible, continuous, and unmolested use of land for a period of time sufficient to acquire an easement by adverse user, the use will be presumed to be under claim of right." (citation omitted)).

90. See, e.g., Kratina v. Bd. of Comm'rs, 548 P.2d 1232, 1235 (Kan. 1976); Albany \& E. R.R. Co., 469 P.3d at 752 .

91. See, e.g., Fullenwider v. Kitchens, 266 S.W.2d 281, 283 (Ark. 1954) (“[T] such land in many instances will not be in position to readily detect or prevent others from crossing over his land, and, even if he did, he might not enter any objection because of a desire to accommodate others and because such usage resulted in no immediate damage to him.").

92. See, e.g., Cedar Beach/Cedar Island Supporters, Inc. v. Gables Real Estate LLC, 145 A.3d 1024, 1028 (Me. 2016) ("The presumption [of permission] serves an important societal purpose in that it allows for greater access to Maine's renowned natural features by permitting landowners to rely on the presumption of permission to protect their ownership interests, rather than encouraging them to take steps to restrict recreational use of their lands.").

93. See, e.g., Fullenwider, 266 S.W.2d at 283; Simon v. Pettit, 687 P.2d 1299, 1301 (Colo.1984) ("[W] here the land is vacant and unoccupied and remains free to public use and travel until circumstances induce the owners to enclose it, the mere travel across it, without objection from the owners, does not enable the public to acquire a public road or highway over the same. Such use by the public of vacant and unoccupied land by travel over it, even after the period of twenty years, is regarded merely as a permissive use." (quoting O'Connell v. Chi. Terminal 
presumption, and some applications of it, do not apply the presumption when the land is occupied or fenced, even though a private rural roadway is left open. ${ }^{94}$ The presumption should apply even in such cases because the same justifications apply. The public use of a private rural road is harmless and not worth preventing, whether the owner occupies the land or not, and whether the rest of the land is enclosed or not. Also, the public has the same interest in enjoying the use of the private rural road, rather than being unnecessarily restricted by landowners who fear otherwise losing their right to exclude in the future, regardless of whether the land is occupied or enclosed.

Some courts have suggested that the presumption does not apply to occupied or enclosed rural land because, if the land is somehow developed but the road left open, the owner has implied a grant of the roadway to the public. ${ }^{95}$ If such an implied grant is the basis for a prescriptive easement, then this reasoning makes sense. But for the great majority of courts that have abandoned the acquiescence element and the lost grant theory of prescriptive easements, ${ }^{96}$ this very same reasoning instead suggests that the public's use is not adverse but is by virtue of permission. By using and even enclosing the land, yet leaving a roadway open for others to use, the owner implicitly grants permission to the public to pass over the roadway. Presuming otherwise encourages rural landowners to inefficiently close private rural roadways, causing them unnecessary expense and the public unnecessary inconvenience.

Some courts have expressed this reasoning in a similar context, declaring that if a road is obstructed by a gate, the use of the road is presumptively permissive rather than adverse. ${ }^{97}$ Of course, if a landowner keeps a gate locked, the owner is

Transfer R.R. Co., 56 N.E. 355, 357 (Ill. 1900))); Cedar Beach/Cedar Island Supporters, Inc., 145 A.3d at 1028; Moravek v. Ocsody, 456 S.W.2d 619, 624 (Mo. Ct. App. 1970); Primark, Inc. v. Burien Gardens Assocs., 823 P.2d 1116, 1121 (Wash. Ct. App. 1992) ("Mere travel over unenclosed land by the public is regarded as permissive rather than adverse and is insufficient to establish a public highway by prescription." (citation omitted)); Lincoln Cty. Bd. of Comm'rs v. Cook, 39 P.3d 1076, 1088 (Wyo. 2002).

94. See Dep't of Nat. Res. v. Cyphers, 74 P.3d 447, 450-51 (Colo. App. 2003) (“Landowner further argues that the nature of the land rendered it presumptively subject to permissive use because it was 'unenclosed and unoccupied.' However, the record contains evidence that there was a fence close to landowner's property and that the property was occupied or regularly used by landowner's predecessors at various times throughout the prescriptive period." (citation omitted)).

95. See Thomas v. City of Rainsville, 502 So. 2d 346, 348 (Ala. 1987) ("When lands are reclaimed, and such ways are left open for use, and are used by the public as highways, these acts may constitute the beginning of a right of prescription; and, if permitted to continue long enough, will raise the presumption of a grant. . . Merely allowing the public to pass over unreclaimed wild lands, will not, however, raise the presumption of dedication." (quoting Rosser v. Bunn \& Timberlake, 66 Ala. 89, 95 (1880))).

96. See supra note 31.

97. See Lang v. Jones, 552 P.2d 497, 499 (Colo. 1976) ("We have held that the use of a road is not adverse where free travel along the road is obstructed by gates across the road, even though they are not locked. The use of a road under such conditions is permissive." (citation omitted)). 
not permitting the public to use the road. If the public nevertheless continues using the road without interruption despite the locked gate, the public surely indicates an adverse claim of right rather than use by virtue of the landowner's permission. ${ }^{98}$ But if a gate is left open or unlocked, the unlocked gate reinforces the presumption that the owner does not object to others using the road and has given implied permission to do so. ${ }^{99}$

This reasoning has led some courts to an inconsistent conclusion which conflicts with the common presumption that use of open, unenclosed land is presumed permissive rather than adverse. Some courts have held that an unlocked gate to control public traffic indicates a permissive use, while an unlocked gate to control livestock does not indicate a permissive use. ${ }^{100}$ But an unlocked livestock gate indicates permission for public use just as much as an unlocked gate for traffic does. In either case, a gate itself does not imply permission to travel on private land. Rather, the owner indicates permission by leaving the gate open or unlocked, just as most courts reason that leaving rural land open and unenclosed indicates permission. ${ }^{101}$ Courts that distinguish between the two types of gates apparently reason that landowners must somehow demonstrate they have granted permission to the public, so the public is aware they are using the road by permission rather than by right. This approach focuses on the public's merited acquisition by long use, fulfilling public expectations, rather than the owner's lost right to exclude because of unjustified delay in asserting the right to exclude. ${ }^{102}$ Although we might fairly assume that any rural landowner who leaves a private

98. Cf. Stone v. Garcia, Nos. 260887(GHP), 263833(GHP), 2007 WL 4531550, at*15 (Mass. Land Ct. Dec. 27, 2007), aff'd, 933 N.E.2d 1033 (Mass. App. Ct. 2010) (finding that locked gate interrupted public's use of road, preventing a public easement by prescription). One Colorado court stated with apparent inconsistency that "the evidence demonstrated that the use of the road had been permissive for ranching purposes only" but also that "the record clearly reveals that plaintiff did object to the use of the road by the public. Indeed, it is undisputed that plaintiffs had erected fences with chains and locked gates on the road." Walter v. Hall, 940 P.2d 991, 995 (Colo. App. 1996).

99. See Kostbade v. Metier, 432 P.2d 382, 386 (Mont. 1967) ("The fact that a road has been barred by gates to be opened and closed by the parties passing over the land has always been considered as strong evidence of a mere license to the public to pass over the designated way." (citations omitted)).

100. See Bd. of Cty. Comm'rs v. Flickinger, 687 P.2d 975, 981 (Colo. 1984); Kostbade, 432 P.2d at 386 (" $[\mathrm{T}]$ his gate was not constructed or maintained in such a way as would show permissive use of the road. . . Its purpose was not to control traffic on the road and it appears that it did not in fact hinder public use of the road. . . The evidence of this one gate, admittedly built not to stop people but cattle, is not enough standing alone to rebut the presumption established by such long public use."); McKenzie Cty. v. Reichman, 812 N.W.2d 332, 342 (N.D. 2012) (“Other courts have also recognized that the use of gates across a road is indicative of a permissive use, but that gates used only for working livestock which are not intended to deny access or interfere with public traffic do not establish a permissive use of a road." (citations omitted)).

101. See supra note 93.

102. See Restatement (Third) of Prop.: Servitudes $\S 2.18 \mathrm{cmt}$. f(Am. Law Inst. 2000); id. $\S 2.17 \mathrm{cmt}$. c; supra note 73 and accompanying text. 
road open to the public has implied permission for the public to use the road, the public is more likely to be aware that the road is on private land if there is a private gate for controlling traffic.

But if a state presumes that use of unenclosed rural land is permissive, as most do, the public use of a rural roadway should be permissive in any case except when the landowners have done something to rebut that presumption, whether by actually locking a gate or otherwise. ${ }^{103}$ Whatever the public perception and expectation, landowners should not lose the right to exclude unless they clearly should have known that their right to exclude was being challenged. ${ }^{104}$ An unlocked livestock gate does not rebut the presumption of permission precisely because it does not purport to prevent public traffic. Consequently, even if other elements are met, public use of rural land for a roadway should, and often will, be presumed to be permissive and therefore will not result in a public easement by prescription. ${ }^{105}$

However, if the government takes control of a roadway, that certainly does indicate an assertion of a public right. ${ }^{106}$ So the government may prove adverse use of a roadway easement by proving that it maintained the roadway for public use for the prescriptive period. ${ }^{107}$ Other acts by the government, like identifying

103. See, e.g., Heller v. Gremaux, 53 P.3d 1259, 1263-64 (Mont. 2002) ("The mere use of a way for the required statutory period is generally not sufficient to give rise to the presumption of a grant, and 'generally some circumstances or act, in addition to the use, tending to indicate that the use was not merely permissive, is required."' (citation omitted)).

104. See id. at 1264 ("Each element of a prescriptive easement claim must be proven by clear and convincing evidence. 'All elements must be proved in a case such as this because one who has legal title should not be forced to give up what is rightfully his without the opportunity to know that his title is in jeopardy and that he can fight for it."' (citations omitted)).

105. See Berger v. Berger, 88 N.W.2d 98, 100 (N.D. 1958) ("Mere user of land by the public as a highway is insufficient of itself to establish a highway by prescription or long use. The user must be adverse and hostile to the rights of the owners; and mere travel by the public does not of itself constitute adverse use of the property by the public. Regardless of how long it is continued, a user by license or permission of the owner of the land sought to be impressed with the public easement of travel is not adverse and affords no basis for prescription." (citations omitted)). But see Trigg v. Allemand, 619 P.2d 573, 577 (N.M. Ct. App. 1980) (“A public highway can be established by use alone. . . 'It is not essential that there be positive evidence that the use of the road by the public was under a claim of right. Such continuous use for twenty years or more, unexplained, will be presumed to be under a claim of right, and therefore adverse."' (citations omitted)).

106. See Boykin v. Carbon Cty. Bd. of Comm'rs, 124 P.3d 677 (Wyo. 2005); Lincoln Cty. Bd. of Comm'rs v. Cook, 39 P.3d 1076, 1091-92 (Wyo. 2002) (holding that evidence did not support Board's findings of adverse use by county; maintenance was periodic blading and plowing, but primarily by request and consistent with policy of plowing other private properties); Koontz v. Town of Superior, 746 P.2d 1264, 1268 (Wyo. 1987).

107. See, e.g., Weidner v. Dep't of Transp. \& Pub. Facilities, 860 P.2d 1205, 1210-11 (Alaska 1993) ("In constructing a road, the government makes a commitment that contemplates continued, unrestricted use of the affected land. In other words, once the State determines a roadway is needed for public access to a certain region, the State surely does not intend such access to be contingent 
the road as a public road on an official map or by signs, likewise ensure that the owner is aware of a claim that the road is public. ${ }^{108}$

Rather than merely holding that public maintenance may rebut the presumption of permissive public use, some states require public maintenance in order for the government to acquire a public road easement by long use. Some state statutes expressly require public maintenance for a specified period ${ }^{109}$ or public maintenance combined with public use. ${ }^{110}$ Some state statutes require only public use, but state courts have construed the statutes to require public maintenance or other governmental manifestation of intent to make the road

upon the permission of a private landowner. . . . Thus, construction and maintenance of a public roadway is a use that contemplates a claim of right rather than the owner's permission. For this reason, we hold that the State's construction and maintenance of Bay Road overcomes any presumption of permissive use." (citation omitted)); Feldker v. Crook, 567 N.E.2d 1115, 1125 (IIl. App. Ct. 1991) ("Maintenance of a road by public authorities is a strong indication that the road is a public highway, and the converse of this proposition is no less compelling." (citation omitted)); Hitshew v. Butte/Silver Bow Cty., 974 P.2d 650, 654 (Mont. 1999) (“'[T]he public's use coupled with a county government's regular maintenance of a roadway without the landowner's permission is evidence of adverse use." (citations omitted)); Kratina v. Bd. of Comm'rs, 548 P.2d 1232, 1237 (Kan. 1976); Cook, 39 P.3d at 1087; Koontz, 746 P.2d at 1269 (reasoning that public maintenance is sufficient if it is "as much as may be necessary to keep the road in substantial repair or to put it in condition for public travel" (citation omitted)).

108. See, e.g., Mo. REv. STAT. § 228.190 (2020) ("All roads in this state that have been established by any order of the county commission, and have been used as public highways for a period of ten years or more, shall be deemed legally established public roads . . . ."); McIntyre v. Bd. of Cty. Comm'rs, 86 P.3d 402, 414 (Colo. 2004); Heller, 53 P.3d at 1264 (holding that public use was insufficient to establish adverse use, and that county had not maintained the road or identified it as a public road in public records).

109. See ARK. Code ANN. § 27-66-201 (2020) ("All public roads in the several counties in this state on which the several county courts have, from time to time, appointed overseers to work, and directed that hands should be apportioned therefor, shall be declared and deemed to be public roads, without regard to any informality of the several county courts, or either of them, by which they were ordered to be declared public roads in their several counties.”); WIS. STAT. § 82.31(2) (2020) ("[A]ny unrecorded highway that has been worked as a public highway for 10 years or more is a public highway....”).

110. See Del. Code ANN. tit. 17, §509 (2020) ("All public roads . . . which have been used as such and maintained at the public charge for 20 years or more are declared to be common highways. The usage by the public for 20 years or more of any road shall not cause the road to become a common highway or public road unless the same has been maintained at the public charge for 20 years or more.”); IDAHO CODE § 40-202(3) (2020) (“[A]11 highways used for a period of five (5) years, provided they shall have been worked and kept up at the expense of the public . . . are highways.”); Mo. REV. STAT. § 228.190 (2020) (“[A]ll roads that have been used as such by the public for ten years continuously, and upon which there shall have been expended public money or labor for such period, shall be deemed legally established roads . ...”); W. VA. CoDE § 17-1-3 (2020) (see infra text accompanying note 115). 
public. ${ }^{11}$ For example, New York's statute states: "All lands which shall have been used by the public as a highway for the period of ten years or more, shall be a highway, with the same force and effect as if it had been duly laid out and recorded as a highway." 112 New York courts have long interpreted this statute to require not just travel along the road by the public but also maintenance by the government. ${ }^{113}$ At least one state, Kansas, has declared judicially that a prescriptive public road easement cannot be acquired by public use alone, but that the government must also have "take[n] some positive action, either formally or informally, such as improving or maintaining the road." 14

Like prescriptive easement statutes generally, these statutes expressly require only proof of public maintenance (and usually also public use) and not the rest of the common law elements. For example, the West Virginia Code states:

Any road shall be conclusively presumed to have been established when it has been used by the public for a period of ten years or more, and public moneys or labor have been expended thereon, whether there be any record of its conveyance, dedication or appropriation to public use or not. ${ }^{115}$

Just as courts have commonly construed other public prescriptive easement

111. See McIntyre, 86 P.3d at 414 ("The evidence [of adverse use under Colo. REV. STAT. § 43-2-201(c) (2020)] must include some overt act on the part of the public entity responsible for roads in the jurisdiction that it considers the road a public road. This notification commences the prescriptive period; without it, the prescriptive period never begins."); Bass v. Pearson, 466 S.E.2d 17, 19 (Ga. Ct. App. 1995) ("However, in order for the county to have acquired the road by prescription, it must have been shown not only that the public used the road for the required period of time [as required by GA. CODE ANN. § 32-3-3(c) (2020)], but also 'that the proper county authorities during that time ... recognized it as a public road by having the same [repaired].... 'The purpose of requiring a showing of repairs is to give notice to the landowner that the prescriber's use is adverse, rather than permissive."' (quoting Dunaway v. Windsor, 30 S.E.2d 627, 631 (Ga. 1944); Jackson v. Stone, 436 S.E.2d 673, 676 (Ga. Ct. App. 1993))). But see WASH. Rev. Code $\S \S$ 36.75.070-.080 (2020). Washington's statute prevents such a construction because it specifies a tenyear prescriptive period for roads "used as public highways" in $\S 36.75 .080$ but a seven-year period for roads "used as public highways" when "they have been worked and kept up at the expense of the public" in $\S 36.75 .070$.

112. N.Y. High. LAW $\S 189$ (McKinney 2020).

113. See, e.g., Johnson v. City of Niagara Falls, 129 N.E. 213, 215 (N.Y. 1920); Usher v. Mobbs, 493 N.Y.S.2d 531, 531 (App. Div. 1985) ("[A] public highway can be created only by public use coupled with maintenance and adoption of the way by the town."); Forest Hills Gardens Corp. v. Baroth, 555 N.Y.S.2d 1000, 1002 (App. Div. 1990) ("However, ... use alone by the public of a private street will not transform the street into a public street under a theory of prescriptive easement. In addition to use by the public, there must also be a finding that the street has been continually maintained or repaired for the statutory period, and thus, adopted by the public authorities for public use." (citations omitted)).

114. Kratina v. Bd. of Comm'rs, 548 P.2d 1232, 1237 (Kan. 1976).

115. W. VA. CoDE $§ 17-1-3(2020)$. 
statutes, ${ }^{116}$ courts might construe these use-plus-maintenance statutes to incorporate the usual common law requirements for prescriptive easements. At least a few courts, however, have reasoned that their state statutes do not merely supplement prescriptive easement doctrine, but create a distinct way to acquire public roadway easements; the statutes clearly and unambiguously state the requirements for acquisition of a public easement, and courts cannot add to those requirements. ${ }^{117}$ Since a common law prescriptive easement would not require public maintenance, one can fairly reason that these statutes do create a new and distinct way to acquire a public easement, despite the similarity to prescriptive easements.

Even if so, these statutes are surely based on the same principles as prescriptive easements. They should therefore be construed and applied in light of those principles.

These statutes, and judicial interpretations of public use statutes like in New York, result from recognition that while landowners may be understandably unaware or unconcerned about use of a road over their property, they certainly should be aware of a public claim if the government has been maintaining a road over their property for years. ${ }^{118}$ Especially when state law doesn't allow public maintenance of private roads, landowners should be aware that such maintenance isn't a public gift to them as private owners; the government is acting as if it has an interest in the road. ${ }^{119}$ As the Supreme Court of Kansas expressed it:

Mere use by the traveling public is ambiguous. . . . On the other hand, where public officials take some positive action, either formally or informally, such as improving or maintaining the road, the intention of the public at least is unmistakable. County commissioners, township

116. See supra note 71.

117. See East Side Highway Dist. v. Delavan, 470 P.3d 1134, 1150 (Idaho 2019) ("There is no explicit hostility requirement set out in the statute for establishing a public highway. Notably, this Court has recently articulated the importance of the strict application of unambiguous statutes. ... Here, the plain language of Idaho Code section 40-202(3) contains only two elements. First, the highway must be used for a period of five years. Second, the highway must be maintained at the public expense. The statute does not contain a requirement for hostile or adverse use by the public.”); Wilson v. Sherman, 573 S.W.2d 456, 459 (Mo. Ct. App. 1978) ("Plaintiffs assert that the user must satisfy certain adjectives open, adverse, notorious, continuous, uninterrupted, exclusive, and hostile. These adjectives are frequently employed to define the user essential to the establishment of a highway by prescription. Establishment of a public road under $\S 228.190$ is a method separate and distinct from establishment by prescription. If the evidence is sufficient to satisfy the requirements of $\ldots \S 228.190 \ldots$, there is no need to determine whether it meets the requirements of an alternate method for establishment of a public road." (footnote and citations omitted)).

118. See, e.g., Kratina, 548 P.2d at 1237.

119. See, e.g., 64 John J. Dvorske et AL., New York Jurisprudence Highways, Streets, AND BRIDGES $\S 92$ (2d ed. 2020) ("A municipality may not expend public funds to improve and maintain a private road; such an expenditure of funds would amount to an unconstitutional gift.”). 
boards and city governing bodies have no authority, and are not frequently known, to devote public money to private roads. When a road is worked by public authorities the owner is chargeable with the knowledge that they do so under a claim of right. ${ }^{120}$

A public maintenance requirement thus ensures notice of a public claim of right. However, if a lightly used rural road requires very little maintenance, maintenance may not ensure notice to the landowner. ${ }^{121}$ Even though a statute doesn't say that the public maintenance must be open and notorious, as usually required for a prescriptive easement, courts should apply a public maintenance requirement consistently with its purpose, considering whether the maintenance is sufficiently frequent, consistent, and visible enough to notify a reasonably diligent owner of a public claim of right. ${ }^{122}$

Public maintenance statutes likewise don't say that the maintenance must be continuous or uninterrupted, ${ }^{123}$ as is usually required of a use to establish a prescriptive easement. ${ }^{124}$ Unlike use, however, maintenance need not be continuous to notify a landowner of a public claim and ensure sufficient time to respond. The government generally maintains roads as needed; those needs may be more or less frequent and regular. Requiring public maintenance to be any more continuous than needs require would be inconsistent with the evident intention of these statutes. ${ }^{125}$ On the other hand, if the statute also requires public

120. Kratina, 548 P.2d at 1237.

121. See, e.g., Brownback v. Doe, 241 P.3d 1023, 1027 (Kan. Ct. App. 2010) (concluding that only two occasions of ditching and grading the road in 100 years were insufficient to give landowner knowledge of public use).

122. See McIntyre v. Bd. of Cty. Comm'rs, 86 P.3d 402, 414 (Colo. 2004) (“"[T]he claimant must provide evidence that a reasonably diligent landowner would have had notice of the public's claim of right to the road. The evidence must include some overt act on the part of the public entity responsible for roads in the jurisdiction that it considers the road a public road."); Brownback, 241 P.3d at 1027 (holding that ditching and grading a road twice in over 100 years was insufficient to acquire a prescriptive easement in road); Villadsen v. Mason Cty. Rd. Comm'n, 706 N.W.2d 897, 903 (Mich. Ct. App. 2005) ("[P]ublic authorities must engage in more than infrequent, minor maintenance to satisfy this element of a highway by user. However, the nature of the road must also be considered in determining whether this element is satisfied. Because the disputed portion of the road in question was a quiet country two-track road with only a minimal amount of traffic, defendant road commission's work on the road was not required to be extensive to satisfy the public work element of a highway by user." (citations omitted)).

123. See, e.g., W. VA. CODE $§ 17-1-3$ (2020).

124. See, e.g., Heller v. Gremaux, 53 P.3d 1259, 1263 (Mont. 2002).

125. See, e.g., State v. Nesbitt, 310 P.2d 787, 790 (Idaho 1957) ("It is not required that a prescriptive road be worked on for five consecutive years, nor does the statute require work to be done throughout the road's entire length, but only requires that such work as may be needed be done when necessary, for the statutory period, in order to acquire a right by prescription."); Liberty Twp. v. Telford, 358 S.W.2d 842, 843 (Mo. 1962) ("The courts of this state, in construing the pertinent language of the above-quoted section (228.190) have held that to show compliance with 
use, even if it doesn't say the use must be continuous, the likely intent would be to require the kind of continuous use that would notify the landowner and satisfy the element of a prescriptive easement claim. ${ }^{126}$

Rural landowners might object that even if they know of public use and maintenance, they have no reason to object if it is light and unintrusive. The use and maintenance benefit the public and don't hurt the owners, so we have no reason to deprive owners of the right to assert their private ownership and object to further public use years later if and when it does conflict with their private interests. However, members of the public may have relied on that public road in their own use and development of their land during that time, so it would be unjust to later deny the public road. Furthermore, if state law prohibits public maintenance of private roads, ${ }^{127}$ property owners who are aware of such public maintenance should not improperly accept the illegal public benefit but should notify the government that they believe the road is not public.

Some state legislatures have recognized the unique circumstances of rural landowners and gone beyond the judicial presumption of permission to prohibit prescriptive easements over rural roadways in certain circumstances. A Texas statute allows counties under 50,000 in population to obtain roadways by "adverse possession" but does not mention prescription. ${ }^{128}$ Texas courts have applied this statute to prevent prescriptive easements to roadways in such counties, unless they were obtained before the statute's effective date. ${ }^{129}$ The statute affirms the common law rule that use with the owner's permission cannot establish adverse possession, but also says that adverse possession "is not established by ... maintenance with public funds of a private road in which a public interest is not recorded." 130 Since 1850, a Pennsylvania statute has prohibited public or private prescriptive rights of way "where such way passes through uninclosed woodland." 131

the requirement that public money or labor shall have been expended for ten years 'continuously' does not require proof of the constant expenditure of money or labor or the expenditure of either money or labor every year for an entire 10-year period, but that there has been compliance when public money or labor has been expended from time to time during any 10-year period, sufficient to maintain the road in reasonably good condition for public travel.").

126. See, e.g., McIntyre, 86 P.3d at 412 ("Sporadic use of the road is not enough to establish adversity or put the property owner on notice of a public claim of right." (citation omitted)).

127. See supra notes $55,119$.

128. Tex. Transp. Code AnN. §§ 281.001-.002 (West 2020).

129. See, e.g., McGraw Minerals, Ltd. v. Cty. of Jasper, No. 13-14-00373-CV, 2015 WL 2163624 (Tex. App. May 7, 2015).

130. TRANSP. $\S 281.004$.

131. 68 Pa. Cons. StAT. $§ 411$ (2020); see also Sprankle v. Burns, 675 A.2d 1287, 1289 (Pa. Super. Ct. 1996) ("This statute applies equally to alleged private and public prescriptive easements."). 


\section{DECLARING A PUBLIC ROAD}

To establish a public road in some states, the government must also declare that a public road exists on the land or easement owned by the government. ${ }^{132}$ This is the result of state statutes, which of course may specify the process by which public roads may be established. ${ }^{133}$ Such a requirement helps ensure that the government does not acquire maintenance obligations and liabilities without directly deciding to do so. ${ }^{134}$ Regardless of how long the government has owned the land or how the land is used, if a statute specifies the process for creating a road, and the statutory process has not been followed, then no public road exists. ${ }^{135}$

Unless a statute says otherwise, this should also be true regardless of how the government came to own the land, even if a roadway is acquired by prescription. ${ }^{136}$ However, some statutes declare that a prescriptive roadway is an official public road regardless of whether the government has taken action to establish and open the road. ${ }^{137}$ Such a rule, especially if combined with a prescriptive easement rule that allows public use without government maintenance to create a public roadway by prescription, creates a risk that the government may end up with obligations and liabilities that it never directly decided to undertake. Washington's statute recognizes this risk and illustrates one way to avoid such a situation:

$[\mathrm{N}]$ o duty to maintain such public highway [acquired by prescription] nor any liability for any injury or damage for failure to maintain such public highway or any road signs thereon shall attach to the county until the same shall have been adopted as a part of the county road system by resolution of the county commissioners. ${ }^{138}$

132. See Cary v. Pulaski Cty. Fiscal Ct., 420 S.W.3d 500, 515-16 (Ky. Ct. App. 2013) (distinguishing the establishment of a road by government resolution and the acquisition of an interest in the land by contract, condemnation, or otherwise).

133. See, e.g., Yeager v. Forbes, 78 P.3d 241, 255 (Wyo. 2003) (applying statute that declared no road was a public road unless established as required by the statute).

134. See Kraus v. Dep't of Commerce, 547 N.W.2d 870, 873 (Mich. 1996) (“[T]he requirement of public acceptance by a manifest act, whether formally or informally, was necessary to prevent the public from becoming responsible for land that it did not want or need, and to prevent land from becoming waste property, owned or developed by no one." (citation omitted)).

135. See, e.g., Stevenson v. Cosgrove, 347 N.E.2d 857, 860 (Ill. App. Ct. 1976) (holding that "there was not an acceptance as a matter of law, since defendant's letter was not in the form of an order purporting to incorporate the subdivision streets into the township road system, and was not filed with the road district clerk as required by the statute"); Yeager, 78 P.3d at 241; Rocky

Mountain Sheep Co. v. Bd. of Cty. Comm'rs, 269 P.2d 314 (Wyo. 1954).

136. See Broek v. Cty. of Washakie, 82 P.3d 269 (Wyo. 2003).

137. See, e.g., ARK. Code AnN. § 27-66-201 (2020) (see supra note 109); N.D. CEnT. COdE $\S 24-07-01$ (2020) (see supra note 70).

138. WASH. ReV. CODE $§ 36.75 .080$ (2020). 
Wyoming law specifies a separate process for creating public roads on roadways acquired by prescription, including filing a plat and survey and publishing and delivering notice. ${ }^{139}$ If no one objects, the road is created. ${ }^{140}$ If someone does object, the board of county commissioners decides whether the roadway was properly acquired by prescription or adverse possession, and the objector can appeal an adverse decision to the district court. ${ }^{141}$

If the public has acquired a prescriptive easement, the absence of required government adoption doesn't mean that the public doesn't have an easement; it only means, in some states, that the road is not an official public road. ${ }^{142}$ Consequently, the public still has the right to travel the road, but the government does not have the duty to maintain the road as a public road. ${ }^{143}$ Some courts have construed state prescription statutes to require some governmental assertion of public ownership, such as maintenance, even though the statutes do not expressly state such a requirement. ${ }^{144}$

State statutes vary in the requirements for declaring a public road, but the usual requirement is that the local governing body adopt the road by resolution. ${ }^{145}$ Statutes may also require some notice to affected landowners and a public hearing. ${ }^{146}$ A state statute may allow residents to initiate the process by petition or otherwise, but the governing body ultimately must decide whether to establish the public road. ${ }^{147}$

139. See Wyo. StAt. ANN. § 24-1-101(a)-(b) (2020).

140. Id. § 24-1-101(a).

141. Id. $\S 24-1-101(\mathrm{~b})$.

142. See, e.g., Brick v. Keim, 25 Cal. Rptr. 321, 324 (Dist. Ct. App. 1962).

143. For example, a California statute says that "[n]o public or private road shall become a county highway until and unless the board of supervisors, or its designee, by appropriate action, has caused the road to be accepted into the county road system. No county shall be held liable for failure to maintain any road unless and until it has been accepted into the county road system by action of the board of supervisors or its designee." CAL. STS. \& High. CODE $\S 941$ (West 2020). In Brick v. Keim, the court reasoned that this statute does not require acceptance in order for the public to have the right to travel the road, but only "protect[s] the political subdivision from responsibility where it has not formally accepted the road as a county highway." Brick, 25 Cal. Rptr. at 324.

144. See McIntyre v. Bd. of Cty. Comm'rs, 86 P.3d 402, 407 (Colo. 2004) (“[T]he public entity responsible for maintaining public roads in the jurisdiction must take some action, formal or informal, indicating its intention to treat the right of way as a public road."); supra notes 111-14 and accompanying text.

145. See, e.g., Ky. Rev. StAt. Ann. $§ 178.115$ (West 2020) ("Whenever the fiscal court of any county deems it to be in the best interest of the county to open, establish or alter the location of any public road, ... the fiscal court shall adopt a resolution setting forth the necessity for the public road or structure, and thereupon the public road or structure shall be deemed opened, established or altered, as the case may be ....”); WYO. STAT. ANN. § 24-3-101(a) (2020).

146. See BRUCE \& Ely, supra note 10, § 5:26.

147. See, e.g., Ariz. Rev. Stat. Ann. § 28-6701(B) (2020); Ark. Code AnN. § 14-298-103 (2020); Mont. Code AnN. § 7-14-2601 (2020); Wyo. Stat. Ann. § 24-3-101(b) (2020). 
A state statute may also allow roads to be established by consent without any other required process. ${ }^{148}$ If all owners of the land over which the road passes give consent, notice to affected landowners and a public hearing may seem unnecessary. However, the local governing body must still consider other important issues in deciding whether to establish a road, including whether to accept the responsibility for its maintenance, a consideration that may be especially important for rural roads whose use may not justify the public expense of maintenance. The public should have an opportunity to be heard on such issues and the governing body should still exercise its discretion whether to establish the road even if all the landowners agree to create a public road.

In some states, accepting a road by dedication or acquiring a public roadway by prescription is enough to establish a public road without any other governmental action. ${ }^{149}$ Some even distinguish between statutory public roads and common law public roads. ${ }^{150}$ The former require compliance with statutory procedures, but the latter may be created by prescription without formal governmental acceptance. ${ }^{151}$

\section{STATUTORY ROAD MAPPING}

Evidence of the acquisition and establishment of many county roads - especially old, infrequently used rural roads - is difficult or impossible to find. ${ }^{152}$ Uncertainty about legal status can continue for many years. One way to address this problem is statutory road mapping that settles some legal uncertainties about public roads collectively in a single process. ${ }^{153}$

148. See Wyo. Stat. AnN. § 24-3-108 (2020).

149. See WorldCom Network Servs., Inc. v. Thompson, 698 N.E.2d 1233, 1240 (Ind. Ct. App. 1998) ("County highways can be established in this state by order of the board of county commissioners, by express grant or by public use.”); Town of Kittery v. MacKenzie, 785 A.2d 1251, 1254 (Me. 2001) ("In Maine, a town way can be created: (1) by the statutory method of laying out and accepting a way; (2) by dedication and acceptance; and (3) by prescriptive use." (footnote and citations omitted)); Breiner v. Holt Cty., 581 N.W.2d 89, 93 (Neb. Ct. App. 1998) (holding that a county resolution declaring long-used roads to be public roads did not create public roads because "the County clearly did not open the public road in any manner authorized by statute or due process," but holding that the road was nevertheless created by prescriptive easement).

150. See Cary v. Pulaski Cty. Fiscal Ct., 420 S.W.3d 500, 508 (Ky. Ct. App. 2013).

151. See id. at 508-09 (“As opposed to 'county roads,' 'public roads' do not require any kind of formal establishment. . . Long continued uninterrupted adverse use of a passway by the public will create an implied acceptance of a dedication of the passway as a public road.").

152. See Wyo. Stat. AnN. § 24-3-201 (2020) ("The legislature finds that due to inaccurate and inconsistent records, there exist roads which are seldom used, not maintained and are not identified as or believed by the public to be county roads but are, in fact, county roads. Recognizing the numerous difficulties resulting from the existence of such county roads, the legislature finds it in the best interest of the public to create a procedure to identify county roads, thereby altering and vacating these abandoned or unnecessary county roads without survey.").

153. See id. 
State statutes commonly authorize or require counties to map existing public roads but with no substantial legal effect. ${ }^{154}$ These road maps seem intended to simply facilitate notice of public roads. ${ }^{155}$ The Idaho statute, for example, authorizes counties to keep official maps, but expressly says counties must acquire and establish roads by other specified methods. ${ }^{156}$ The inclusion or omission of the road from the map has no legal effect. ${ }^{157}$ Such a statute may encourage or require comprehensive road mapping, but since the map does not affect the legal status of roads, no one can rely upon the map to determine the legal status of a road.

Texas and Wyoming, however, have adopted statutes that give the road map the legal effect of establishing and/or vacating a road. ${ }^{158}$ These statutes authorize but do not require counties to adopt such a map. ${ }^{159}$ Texas adopted its statute in 2003 , giving counties the option to map their roads by 2009 , later extended to $2011 . .^{160}$

154. See, e.g., Colo. Rev. Stat. § 43-2-110 (2020); Del. Code Ann. tit. 9, § 6809 (2020); Ga. Code ANN. §§ 32-4-2(f), -40, -41(4) (2020); IDAHo CODE § 40-202(1), (6) (2020); 605 ILL. Comp. STAT. 5/5-103, -105 (2020); Miss. CodE ANN. §§ 65-7-4 to -4.1 (2020) (requiring counties to adopt a map of all county roads, but declaring that the map does not "lay out, open, designate or otherwise establish new public roads, but . . document[s] and record[s] existing roads."); N.J. Stat. Ann. §§ 27:16-2, -4 (West 2020); Ohio Rev. Code AnN. § 5543.04 (West 2020); S.D. Codified LAws $\S \S 31-3-8,-12-7$ (2020); TENN. CodE ANN. § 54-18-208 (2020) (“[T]he adoption or amendment of an official map by the legislative body shall not constitute the opening or establishment of any highway or the taking or acceptance of any land for highway purposes."); UtAH Code ANN. § 72-3-107(1) (West 2020) ("The county executive of each county shall determine all county roads existing in the county and prepare and keep current plats and specific descriptions of the county roads.").

155. See Ga. Code ANN. § 32-4-41(4) (2020) (“A county shall keep on file in the office of the county clerk, available for public inspection, the map of the county road system prepared by the department....”).

156. See IDAHO CODE $\S 40-202$ (7) (2020) ("Prior to designating a new highway or public right-of-way on the official map, the board of county or highway district commissioners shall . . . have some basis indicating dedication, purchase, prescriptive use or other means for the creation of a highway and public right-of-way with evidentiary support.").

157. See id. $\S 40-202(8)$ ("The inclusion or exclusion of a highway or public right-of-way from such a map does not, in itself, constitute a legal determination of the public status of such highway or public right-of-way.”); Halvorson v. N. Latah Cty. Highway Dist., 254 P.3d 497, 503 (Idaho 2011) ("[I]f a road is not properly created as a public highway, its inclusion on an official county highway system map does not make it so ...." (quoting Homestead Farms, Inc. v. Bd. of Comm'rs, 119 P.3d 630, 637 (Idaho 2005))).

158. See Tex. Transp. Code Ann. $\S \S 258.001-.007$ (West 2020); Wyo. Stat. Ann. §§ 24-3201 to -206 (2020).

159. See Wyo. Stat. AnN. § 24-3-203 (“"[W]hen it finds the public interest so requires, the board may initiate the identification procedure under this act for county roads in the county by adopting a resolution to which maps shall be incorporated by reference ....").

160. TRANSP. $§ \S 258.002, .007 ; 2009$ Tex. Gen. Laws 1303. 
If this kind of road identification procedure is optional for counties, one would generally expect that counties would go to the trouble and expense only if they felt that they would get enough benefit from the process. One possible benefit is settling the public ownership of roads that the county claims but which it cannot easily prove were properly acquired and established. The Texas statute allowed counties to propose a road map that "includes each road in which the county claims the existence of a public interest" under any law, including a statutory chapter dealing with dedication and adverse possession in counties of 50,000 or less, or simply by "having continuously maintained the road" before September 1, 1981. ${ }^{161}$ A county thus could include a road on the map even if it had no evidence of a public right other than that the county had long maintained the road.

In Wyoming, on the other hand, the statute does not offer such a benefit to counties. The statute specifies that " $[t]$ he identification procedure under this act shall not be used to establish a county road which was not previously established under other law." ${ }^{162}$ This difference in statutory effect may explain why, even though the procedure was voluntary, all or nearly all of the 200 Texas counties with populations under 50,000 took the opportunity to identify their roads, ${ }^{163}$ while many Wyoming counties have not.

The statutes differ in the effect of both including and not including a road on the map. In Texas, the process allowed counties to resolve the public status of roads that otherwise would be uncertain. It didn't have the same benefit for private owners, however, because omission of a road from the map doesn't necessarily mean the road is not public. Roads that were previously acquired "by purchase, condemnation, dedication, or a court's final judgment of adverse possession" remain public roads even if not included on the road map. ${ }^{164}$ But the statute does seem to assure private owners that roads that were merely used or maintained by the public, but not included on the map, are not public roads.

In Wyoming, on the other hand, the primary objective of the road identification statute is not to settle the public status of old rural roads, but to abandon or vacate unwanted county roads. ${ }^{165}$ Consequently, the statute directs that any road not included in the map is thereby vacated, ${ }^{166}$ unless it was currently

161. TRANSP. $\S 258.002$.

162. Wyo. StAT. AnN. § 24-3-203(c).

163. County Road Clarification, Tex. County Progress (July 1, 2011), http:// countyprogress.com/county-road-clarification/ [https://perma.cc/P4L6-UTLB].

164. TRANSP. $§ 258.002$ (g) ("The failure to include on a county road map adopted under this section a road in which the county has previously acquired a public interest by purchase, condemnation, dedication, or a court's final judgment of adverse possession does not affect the status of the omitted road.").

165. Wyo. Stat. AnN. § 24-3-201 (2020) (see supra note 152). In contrast, Mississippi requires a county road map and register, but omission of a road from the map does not abandon the road. See Miss. Code ANN. § 65-7-4.1 (2020); Abandonment of Roads, Miss. Op. Att'y Gen. No. 2000-0756, 2001 WL 169622 (Jan. 12, 2001).

166. Wyo. Stat. AnN. § 24-3-206 (2020). 
identified and maintained. ${ }^{167}$

Statutory road mapping requirements can be an effective way to resolve uncertainties about the status of rural roads. Of course, the effects of mapping should depend on the legislative objectives. If a legislature wants to most fully resolve the problem of uncertainty about the status of rural roads, a statutory map process should both conclusively settle the establishment of a public road, as in Texas, and the vacating of a public road, as in Wyoming.

If the mapping process has such legal effects, interested parties should have plenty of time and opportunity to challenge the inclusion or omission of any road from the map: a private landowner might challenge the inclusion of a road, while the public might challenge the omission of a road. A landowner's challenge to the inclusion of a road is a challenge to the deprivation of private property, so the mapping process must at least satisfy the notice and hearing requirements of the Due Process Clause. ${ }^{168}$ Wyoming's statute requires public notice and requires any objections and claims to be filed within thirty days after the last notice. ${ }^{169}$ In Texas, however, property owners could challenge the county's claim to any mapped road in a public hearing or within two years of the adoption of the map. ${ }^{170}$ Any mapped road not successfully challenged was conclusively established as a public road. ${ }^{171}$

Furthermore, while the mapping process can settle the status of a road, if the road had not been legally acquired before the mapping process, a landowner has a claim for just compensation when the mapping process takes her private property for public use. ${ }^{172}$ The mapping process can be a way to acquire a road, but it cannot constitutionally circumvent the legal necessity of somehow acquiring the road.

If road mapping is voluntary and a county chooses not to engage in the process, then the statute obviously will not achieve its objectives in that county. Road mapping, along with resulting challenges, is likely to be a long, costly process. Counties understandably may oppose compulsory mapping because of the money and other resources it requires. Rural counties, where the need for mapping is likely to be the greatest, may be least equipped to engage in the mapping process. If mapping can conclusively establish public roads, counties may feel enough incentive to undertake the process, as in Texas. But to most fully accomplish the legislative objectives, the statute would require all counties to map. Politically, that might necessitate state funding and other support for counties.

167. Id. $\S 24-3-203(\mathrm{c})$.

168. See U.S. Const. amend. XIV; Evers v. Cty. of Custer, 745 F.2d 1196, 1203 (9th Cir. 1984) (holding that county declaration of a public road was a deprivation of private property and therefore the county "may have violated Evers's right to due process if it declared the road public without giving her notice and an adequate opportunity to be heard").

169. Wyo. Stat. AnN. $\S ~ 24-3-204$ to -205 (2020).

170. Tex. Transp. Code ANN. $\S \S 258.002, .004$ (West 2020).

171. Id. § 258.003 .

172. See U.S. Const. amend. V. 
A Vermont statute illustrates a mandatory mapping approach to eliminate unused and unwanted public roads, though it applies only to towns and not counties. The statute, enacted in 2006, eliminated "unidentified corridors"- previously unmapped public roads that were not "clearly observable by physical evidence" - unless the town reclassified the roads and mapped the roads by July $1,2015 .{ }^{173}$ The statute thus provided a process to both eliminate old unused roads as well as a process to reclassify and preserve unused public roads.

\section{NOTICE OF A PUBLIC ROAD}

Just as with other interests in land, a public roadway isn't enforceable against landowners who buy their land without required notice of the roadway. ${ }^{174}$ Normally, land buyers have actual notice of a public roadway simply by seeing the public drive across it, so notice requirements are especially important in rural settings where a roadway may have been acquired but never used, or very infrequently used in ways that might not fairly notify a land buyer that a road is public. ${ }^{175}$

State statutes and judicial opinions vary on what notice is required. State statutes generally require a survey or map of a public road to be maintained in some public record. ${ }^{176}$ Road maps and records may be kept by a county engineer or similar official who oversees county roads. ${ }^{177}$ But most state statutes require that official road maps and other documents be filed with the county clerk or other official along with other real property title documents. ${ }^{178}$ A Wyoming

173. Vt. Stat. ANN. tit. 19, §§ 302, 305 (2020); see also Doncaster v. Hane, 229 A.3d 1026, 1031-33 (Vt. 2020); Eric Goldwarg, Note, Known Unknowns: Ancient Roads in Northern New England, 33 VT. L. REV. 355 (2008).

174. See, e.g., City of Lakewood v. Mavromatis, 817 P.2d 90, 96 (Colo. 1991).

175. See Littlefield v. Bamberger, 32 P.3d 615, 618 (Colo. App. 2001) (affirming finding that landowners did not have actual notice of unbuilt county road along boundary line between adjacent ranches).

176. See, e.g., GA. Code ANN. § 32-4-41 (2020) (“A county shall keep on file in the office of the county clerk, available for public inspection, the map of the county road system prepared by the department ....”); N.J. STAT. ANN. § 27:16-2 (West 2020) (“A copy of the resolution, together with the map or maps attached, certified by the clerk of the board shall, within thirty days after the adoption of the resolution, be filed in the office of the county clerk for public inspection."); supra note 154 .

177. See, e.g., WASH. ReV. CODE $§ 36.80 .040$ (2020).

178. See, e.g., Colo. REv. STAT. § 43-1-202.7 (2020) (“[D]ocuments vacating or abandoning such roadway ... shall be recorded in the office of the clerk and recorder of the county . ..."); 605 ILl. Comp. STAT. 5/5-101.8 (2020); IND. CodE § 8-23-23-1 (2020) ("Whenever a right-of-way or easement for a state, county, or municipal highway is acquired, an accurate description of all rightsof-way and easements shall be filed in the office of the recorder of the county in which the real property is located.”); KY. REV. STAT. ANN. § 178.320 (West 2020); S.D. CoDIFIED LAWS § 31-3-8 (2020) ("A certified copy of the resolution and order shall be filed with the register of deeds."); UtAH CODE ANN. § 72-3-107(2)(a) (West 2020) ("The plats and specific descriptions shall be kept 
statute requires keeping the plat and survey of an established road in a road book, a copy of which will be filed with the county clerk. ${ }^{179}$ However, the Wyoming Supreme Court has held that as long as such a book is available to the public, it does not matter whether the book is maintained by the county planning office, the county transportation department, the county clerk, or any other public office. ${ }^{180}$

While a knowledgeable title searcher could certainly include separate road records in a title search, requiring recording in real property records involves minimal administrative burden and reduces the risk that parties will pay value for interests in land without actually knowing that the land is encumbered by a public road easement. State law therefore should require recording notice of public roads in the real property records, so that title searchers need not track down road records in some other place.

Even if the state statute doesn't directly say that public road documents must be recorded with real property records, the state recording act might have the same practical effect. If the state statutes about road creation do not clearly say that some other action gives constructive notice of a road to prospective buyers of the land, ${ }^{181}$ the state's recording act generally should apply to make the government's unrecorded interest in a roadway unenforceable against a purchaser who did not have actual or other constructive notice of the roadway. ${ }^{182}$ The

on file in the office of the county clerk or recorder."); WYo. STAT. ANN. § 24-3-118(e)-(f) (2020); Mavromatis, 817 P.2d at 96 ("We conclude that section 2972 was intended to require the recording of the road petition in compliance with recording act procedures, including entry in the reception book and grantor and grantee indices. We further conclude that placing the road petition in the road book completed a process effecting substantial compliance with the statute for the purpose of creation of a public highway, but absent adherence to the recording act procedures, the road petition did not give constructive notice to subsequent purchasers."); Cary v. Pulaski Cty. Fiscal Ct., 420 S.W.3d 500, 516 (Ky. Ct. App. 2013) ("The county clerk is then required by statute to keep a complete record of all documents of title to rights-of-way, whether acquired by gift, purchase or condemnation." (citation omitted)). But see IDAHO CODE $\S$ 40-202 (2020) (requiring county to either record document establishing public interest in roadway or amend the official road map to include the acquired roadway).

179. Wyo. Stat. Ann. § 24-3-109 (2020).

180. See King v. Bd. of Cty. Comm'rs, 244 P.3d 473, 483 (Wyo. 2010).

181. See Fuller-Ahrens P'ship v. S.C. Dep't of Highways \& Pub. Transp., 427 S.E.2d 920, 922 (S.C. Ct. App. 1993) (noting that under state statute at the time, filing of highway right-of-way deed with state highway department "provided a record sufficient 'to impart notice,' .. . 'just as though such transaction[ ] [was] recorded in the county where the land is situate" (quoting S.C. CoDE ANN. § 57-5-560 (1976) (repealed 1987))). But see State ex rel. Highway Comm'n v. Meeker, 294 P.2d 603, 607 (Wyo. 1956) (holding that including road easement in county road book as required by statute gave sufficient notice to purchaser even though "[t]he legislature has not specifically provided that the proceedings of the board shall be constructive notice").

182. See State v. Cinko, 292 N.E.2d 847 (Ind. Ct. App. 1973); First Am. Title Ins. Co. v. J.B. Ranch, Inc., 966 P.2d 834, 839 (Utah 1998) (holding that road maps required by statute, although on file with county clerk, did not give constructive notice under recording statute, applying "[t]he general rule, ... that in the absence of an express declaration in the statute, records and documents 
Supreme Court of Colorado, for example, held that while putting a road petition in a public road book created a public road by statute, it did not give constructive notice to a purchaser of the land. ${ }^{183}$ The Supreme Court of Indiana similarly held that compliance with a former statute requiring filing a roadway easement in the state highway department only completed the process of establishing the roadway, but did not give constructive notice to a purchaser, and the purchaser was therefore not subject to the roadway under the state's recording statute. ${ }^{184}$ However, even if the government's easement itself is unrecorded, a purchaser might have constructive notice if a reasonable inspection of the land would reveal the roadway ${ }^{185}$ or if the purchaser's chain of title somehow referred to the easement in a way that would prompt a reasonable purchaser to investigate and discover the easement. ${ }^{186}$

State marketable title acts may also protect land purchasers from even recorded public roadways that are not being used and maintained. Minnesota's marketable title act, for example, makes a local roadway unenforceable forty years after recording unless the locality can prove "present, actual, open, and exclusive" possession. ${ }^{187}$ Wisconsin, on the other hand, has held that a state statute expressly recognizing unrecorded town roads indicates that the state's marketable title act does not apply to make unrecorded town roads

filed pursuant to statute do not impart constructive notice" (citations omitted)); Ellingsen v. Franklin Cty., 810 P.2d 910 (Wash. 1991) (holding that recording in county engineer's office did not give constructive notice under recording statute).

183. Mavromatis, 817 P.2d at 96 ("[A]bsent adherence to the recording act procedures, the road petition did not give constructive notice to subsequent purchasers. Subsequent purchasers without actual notice of road petitions appearing in the road book, therefore, are entitled to the protections of the recording act.").

184. See State v. Anderson, 170 N.E.2d 812 (Ind. 1960).

185. See Nampa Highway Dist. No. 1 v. Knight, 462 P.3d 137, 144 (Idaho 2020) ("We hold that the existence of the Road was sufficient to impart constructive notice ... . Although NHD was only in physical possession of a portion of the land conveyed in the Deed of Right-of-Way and there were no physical indications on the property itself signifying that NHD had a claim to an additional twenty-two feet of highway from the centerline, the existence of the Road alone is notice enough to excite the attention of a reasonable person and prompt him or her to inquire further."); State v. Jewell, 26 N.W.2d 825 (Wis. 1947) (holding that even though deed to state was unrecorded, visible occupation of part of the state highway land gave purchasers notice of state's interest).

186. See Jefferson Cty. v. Mosley, 226 So. 2d 652, 658-59 (Ala. 1969); N.C. State Highway Comm'n v. Wortman, 167 S.E.2d 462, 466 (N.C. Ct. App. 1969) (“"If the facts disclosed in an instrument appearing in a purchaser's chain of title would naturally lead an honest and prudent person to make inquiry concerning the rights of others, these facts constituted notice of everything which such inquiry, pursued in good faith and with reasonable diligence, would have disclosed.'” (citation omitted)).

187. Ravenna Twp. v. Grunseth, 314 N.W.2d 214, 219 (Minn. 1981) (citations omitted); MinN. STAT. $§ 541.023$ (2020). 
unenforceable. ${ }^{188}$

However, the language of the road statute or the recording statute might lead to a different conclusion in some circumstances. An Indiana court held that a former road creation statute required filing with the county auditor but not the county recorder, and that the state's recording statute "refers to the conveyance, mortgage or lease of lands but does not require that a public highway right-ofway established by law be recorded in the recorder's office." 189 The court reasoned that the public right in question was not obtained by a "conveyance" of any interest from a grantor to the public; it was the result of a statutory process following a petition by landowners. ${ }^{190}$ The recording statute therefore did not protect good faith purchasers from the public rights established by the county commission's road improvement order. ${ }^{191}$

Similarly, the Supreme Court of Wyoming held that the recording statute did not protect a purchaser from a county road easement acquired by eminent domain but not recorded in the county's real property records. ${ }^{192}$ The court reasoned that acquisition of title by eminent domain was not a "conveyance" which would be void against a good faith purchaser under the statute because it was "against the consent of the owner." "This reasoning seems inconsistent with the applicable statutory definition of "conveyance," which included "every instrument in writing by which any estate or interest in real estate is created . . . or by which the title to any real estate may be affected in law or in equity." 194 At least upon payment of the compensation ordered, an order of condemnation certainly creates an interest in real estate or affects the title to real estate. ${ }^{195}$ The court also noted that the state legislature subsequently adopted a statute requiring interests acquired by eminent domain to be recorded in county real property records, ${ }^{196}$ as other states commonly require. ${ }^{197}$ Nevertheless, buyers and those who represent them should

188. See City of Prescott v. Holmgren, 721 N.W.2d 153, 156 (Wis. Ct. App. 2006).

189. WorldCom Network Servs., Inc. v. Thompson, 698 N.E.2d 1233, 1239 (Ind. Ct. App. 1998).

190. See id. at 1239-40.

191. See id.

192. State Highway Comm'n v. Meeker, 294 P.2d 603, 605 (Wyo. 1956).

193. Id.

194. Id.

195. See 27 Am. Jur. 2D Eminent Domain $§ 780$ (2020).

196. Id.; see also Wyo. STAT. ANN. § 24-3-118(e) (2020) ("A certificate, authorized by the board of county commissioners and signed by its chairman, setting forth the legal description of the property taken shall be recorded in the office of the county clerk, and indexed in like manner and with like effect as if it were a conveyance of the easement or right-of-way from said owners to the county.").

197. See, e.g., ARIz. REv. StAT. ANN. § 12-1126 (2020) (“A copy of the [condemnation] order shall be recorded in the office of the county recorder of the county or counties in which the property is located, and thereupon the property described shall vest in plaintiff for the purposes therein specified.”); CAL. Civ. Proc. Code $§ 1268.030$ (c) (West 2020) (“Any party affected by the order may thereafter record a certified copy of the order in the office of the recorder of the county in 
determine whether applicable state law might make a condemned roadway easement enforceable against them even if not included in the county real property records.

The Supreme Court of Idaho has identified another statutory reason for holding that a state recording statute didn't protect purchasers without notice of an unrecorded county road: the state statute specifying the process for abandoning public roads. ${ }^{198}$ In Trunnell v. Fergel, the court assumed or implied that, even though the public road had been validly created and recorded in a road book as required by statute, it was unrecorded under the state's recording act because it was not recorded in the real property records. ${ }^{199}$ Nevertheless, the court found that the recording statute did not protect the subsequent purchasers of the land:

[A]pplying the bona fide purchaser for value defense would vitiate any interest the county had in County Road 32, a public highway. By extinguishing that interest, this would be akin to abandonment. Because I.C. § 40-203 establishes the only avenues through which a validly created public road may be abandoned, the bona fide purchaser defense

which the property is located . . . . Title to the property vests in the plaintiff upon the date of recordation.”); IDAHO CODE § 7-716 (2020); MD. RULE 12-212(a) (2020) (“Upon the entry of judgment for the plaintiff for the property condemned and the filing of a certification by the plaintiff that the award has been paid to the defendant or into court, the clerk shall record the inquisition among the land records of the county in the same manner in which deeds are recorded."); MASS. GEN. LAws ch. 79, § 3 (2020) ("The board of officers by whom an order of taking has been adopted . . . shall within thirty days thereafter cause a copy thereof, signed by them or certified by their secretary or clerk, or, in case of a taking by or on behalf of a city by a board of officers having no secretary or clerk, certified by the city clerk, to be recorded in the registry of deeds of every county or district in which the property taken or any of it lies."); Mo. REV. STAT. $\S 523.040(1)$ (2020); Mont. CodE ANN. § 70-30-309(2) (2020) (“A copy of the [condemnation] order must be filed in the office of the county clerk and recorder, and upon filing, the property described in the order vests in the condemnor for the purposes specified in the order."); NEV. REV. STAT. $\S 37.160$ (2020) ("A copy of the [condemnation] order shall be recorded in the office of the recorder of the county, and thereupon the title to the property described therein shall vest in the plaintiff ....”); N.D. CENT. Code § 32-15-27 (2020); UtAH Code ANN. § 78B-6-516 (West 2020). But see COLO. REV. STAT. § 38-3-104 (2020) ("Thereafter, the same shall be the property of the petitioner, and a certified copy of the order may be filed for record with the county clerk and recorder of the county in which such lands, rights-of-way, or other rights or easements in lands are located. Such record shall be notice ....”); Boston Water \& Sewer Comm'n v. Commonwealth, 834 N.E.2d 1205, 1209 (Mass. App. Ct. 2005) (holding that condemnation did not need to be recorded because statute declared condemnation of specific property "notwithstanding any . . . general or special law to the contrary" (citation omitted)).

198. See Trunnell v. Fergel, 278 P.3d 938 (Idaho 2012).

199. Id. at 941-42; see also Nampa Highway Dist. No. 1 v. Knight, 462 P.3d 137, 143-44 (Idaho 2020) (indicating that purchaser without other notice of highway easement would not be subject to unrecorded easement). 
is not available .... ${ }^{200}$

Abandonment is quite different from unenforceability under the recording statute: the former is a governmental decision to relinquish a public interest ${ }^{201}$; the latter is a protection for innocent private parties. ${ }^{202}$ Even so, the Idaho statute at the time said: "Until abandonment is authorized by the commissioners, public use of the highway or public right-of-way may not be restricted or impeded . ..." ${ }^{203}$ So even though the statute didn't directly say it provided the only way to extinguish a public road, it did say that public use could not be restricted or impeded until an authorized abandonment. On the other hand, the recording statute said: "Every conveyance of real property other than a lease for a term not exceeding one (1) year, is void as against any subsequent purchaser or mortgagee of the same property, or any part thereof, in good faith and for a valuable consideration, whose conveyance is first duly recorded." ${ }^{204}$ As the court implicitly acknowledged, conveyances of easements are certainly "conveyances of real property," and the recording statute makes no exception for conveyances to the government. ${ }^{205}$ The plain language of both statutes thus applied to produce conflicting results.

Although the court in Trunnell did not state or apply any rules of construction to resolve the conflict, one relevant rule of construction is that, "where two statutes appear to apply to the same case or subject matter, the specific statute will control over the more general statute." 206 A court in this situation could reason that a statute specifically about public roadways would prevail over the general recording statute that applies to all kinds of property conveyances.

Buyers, lenders, and other interested parties therefore should be aware of state requirements for recording public roadway easements and the possibility that some public roadway easements might be enforceable against them even if not visible and not in the county real property records. If they don't search the relevant road records, wherever required to be kept, they may discover too late that their interests are subject to public roads.

\section{EXTINGUISHING PUBLIC ROADS}

Not only may legal issues about acquisition, creation, and notice make the status of a rural road uncertain, but also a long period of nonuse and

200. Trunnell, 278 P.3d at 942.

201. See Leisz v. Avista Corp., 232 P.3d 419, 420 (Mont. 2010) (“Abandonment must be proven with words or acts that indicate a clear intent to abandon. Mere nonuse does not establish abandonment." (citations omitted)).

202. See, e.g., City of Lakewood v. Mavromatis, 817 P.2d 90, 96 (Colo. 1991).

203. Trunnell, $278 \mathrm{P} .3 \mathrm{~d}$ at 941 (citations omitted).

204. IDAHO CODE $\S 55-812$ (2020).

205. See Trunnell, 278 P.3d at 942 ("Generally, '[o]ne who purchases land expressly subject to an easement, or with notice, actual or constructive, that it is burdened with an existing easement, takes the land subject to the easement."' (citation omitted)).

206. State v. Barnes, 987 P.2d 290, 294 (Idaho 1999). 
governmental neglect may create such uncertainty. If no one has used or maintained a public road for many years, landowners might understandably think it isn't a public road.

However, in many states, nonuse of a road by the public does not abandon the road, ${ }^{207}$ just as nonuse of a private easement generally does not result in loss of the easement. ${ }^{208}$ Furthermore, the public has a substantial interest in public roads, so the failure of governmental officials or agents to perform public duties should not have the power to deprive the public of such valuable interests. Therefore, mere failure to maintain a road also should not result in abandonment of a public road. ${ }^{209}$

However, some states do allow abandonment by long nonuse and/or lack of public maintenance. ${ }^{210}$ In Missouri, for example, "nonuse by the public for five years continuously of any public road shall be deemed an abandonment and vacation of the same." ${ }^{211}$ A New York statute says town highways and rights-ofway are abandoned by six years of nonuse, although there is no comparable statute regarding county roads. ${ }^{212}$ Such laws have the virtue of validating what has been happening on the ground for a long time, and therefore perhaps fulfilling

207. See, e.g., Pass v. Forestar GA Real Estate Grp., 787 S.E.2d 250, 253 (Ga. Ct. App. 2016); Feldker v. Crook, 567 N.E.2d 1115, 1124 (Ill. App. Ct. 1991); Villadsen v. Mason Cty. Rd. Comm'n, 706 N.W.2d 897, 908 (Mich. Ct. App. 2005); Soup Creek LLC v. Gibson, 439 P.3d 369, 376 (Mont. 2019); Gill v. Gerrato, 940 A.2d 233, 237 (N.H. 2008); K \& A Acquisition Grp. v. Island Pointe, LLC, 682 S.E.2d 252, 259-60 (S.C. 2009); State v. Harvey Real Estate, 57 P.3d 1088, 1092 (Utah 2002); Benson v. Hodgdon, 992 A.2d 1053, 1059 (Vt. 2010).

208. See Leisz v. Avista Corp., 232 P.3d 419, 420 (Mont. 2010) (“Abandonment must be proven with words or acts that indicate a clear intent to abandon. Mere nonuse does not establish abandonment." (citations omitted)); 3 Tiffany REAl Property $\S 825$ (3d ed. 2019).

209. See, e.g., Kennedy v. McBride, 939 So. 2d 691, 694 (La. Ct. App. 2006) (“[F]ailure to maintain alone is not sufficient to strip the road of its public status."); Benson, 992 A.2d at 1059.

210. See Me. StAT. tit. 23, § 3028 (2020) ("It is prima facie evidence that a town or county way not kept passable for the use of motor vehicles at the expense of the municipality or county for a period of 30 or more consecutive years has been discontinued by abandonment. A presumption of abandonment may be rebutted by evidence that manifests a clear intent by the municipality or county and the public to consider or use the way as if it were a public way."); Laney v. Garmon, 66 So. 3d 766, 769 (Ala. Civ. App. 2010) (stating that nonuse for twenty years abandons a public road); Nichols v. Town of Oxford, 191 A.3d 219, 224-25 (Conn. App. Ct. 2018) ("A previously established highway 'may be extinguished . . . by nonuser by the public for a long period of time with the intention to abandon .... Most frequently, where abandonment has been held established, there has been found present some affirmative act indicative of an intention to abandon ... but nonuser . . . may be sufficient to signify the requisite intention and justify a conclusion of abandonment.", (footnote and citation omitted)); Kennedy, 939 So. 2d at 694 ("Nonuse for more than ten years may be sufficient to establish abandonment."); Gay v. Dube, 39 A.3d 52,55 (Me. 2012) (stating that common law abandonment is presumed by twenty years of nonuse).

211. Mo. Rev. Stat. § 228.190 (2020); see also McCullough v. Doss, 318 S.W.3d 676, 67879 (Mo. 2010) (holding that the statute applies to any public road).

212. N.Y. High. LaW $\S 205$ (McKinney 2020). 
expectations as well. They certainly can benefit private landowners burdened by unused public roads, enabling extinguishment of such roads without official public action. But they can contribute to the uncertain legal status of rural roads, because even rare public use will generally prevent a finding of abandonment in these states, ${ }^{213}$ and interested parties generally won't be able to readily determine if a road has not been used or maintained for the statutory period, or even more uncertainly, for a sufficiently long period of time to indicate intent to abandon.

Some courts have said that the government may be estopped from using a roadway if nonuse is combined with actions reasonably inducing detrimental reliance by landowners. ${ }^{214}$ However, some others have reasoned that such acts by government officials cannot result in loss of a public roadway if such actions are not properly authorized. ${ }^{215}$

Similarly, some states find public abandonment of a roadway when nonuse is combined with some other manifestation of intent to abandon, regardless of private reliance. ${ }^{216}$ This rule, at least in principle, ensures that the public doesn't

213. See, e.g., Auerbach v. Parker, 544 So. 2d 943, 946 (Ala. 1989) (“The fact that travel on the road may have decreased does not work an abandonment so long as it is open for use by the public generally and is being used by those who desire, or have the occasion, to use it." (citation omitted)); Laney, 66 So. 3d at 769 (finding evidence insufficient to prove abandonment even though road "was infrequently used, . . . in a bad state of repair, and . . . not maintained by the county”); McNeely v. Jacks, 526 So. 2d 541, 545 (Miss. 1988); Anderson v. Richards, 608 P.2d 1096, 1099 (Nev. 1980) ("No authority has been cited by appellants that would support a contention that a public road may be deemed abandoned because of use by only a few members of the public or because of a substantial reduction in the number of the members of the public who continue to make use of the rights previously acquired.").

214. See, e.g., Chamness v. Mays, 15 N.E.3d 496, 504-05 (Ill. App. Ct. 2014) ("To create an equitable estoppel against the public, the city must have long withheld the assertion of control over the portion of the street in question, private parties must have been, by the acts of those representing the public, induced, in good faith, to believe the street had been abandoned by the public, and the private party must have erected structures on the street, or made improvements thereon of such a lasting and valuable character that to permit the public to assert the right to repossess itself of the premises would entail such a great pecuniary loss and sacrifice upon the private party that justice and right would demand that the public be estopped." (citation omitted)); City of Myrtle Beach v. Parker, 197 S.E.2d 290, 297 (S.C. 1973).

215. See K \& A Acquisition Grp. v. Island Pointe, LLC, 682 S.E.2d 252, 260 (S.C. 2009); Bd. of Cty. Comm'rs v. White, 547 P.2d 1195, 1199 (Wyo. 1976).

216. See Montanaro v. Aspetuck Land Tr., Inc., 48 A.3d 107, 120-21 (Conn. App. Ct. 2012) ("While nonuse of the highway may, in some circumstances, conclusively establish the intent to abandon[,] where abandonment is found there most frequently is some affirmative act of an intention to abandon." (citations omitted)); Baertsch v. Cty. of Lewis \& Clark, 845 P.2d 106, 111 (Mont. 1992) ("One of the elements necessary to prove abandonment of public property by governmental entities is a showing of a clear intent to abandon. The conduct claimed to demonstrate this intent must be of character so decisive and conclusive as to indicate a clear intent to abandon. The conduct must be some affirmative official act, and not mere implication." (citation omitted)); Millard v. City of Sioux Falls, 589 N.W.2d 217, 219 (S.D. 1999) ("To vacate or abandon 
lose a roadway unintentionally, but only after a public authority takes some kind of action that indicates the intent to abandon. However, it may not ensure that the decision to abandon is made by the elected officials who have the authority to make the decision, if actions by road departments may manifest intent, for example. ${ }^{217}$ This rule also doesn't ensure that the public has an opportunity to object to abandonment and advocate for keeping a roadway. ${ }^{218}$ And it may not reduce the uncertainty about the legal status of a road, since an interested party may not be able to readily determine what the government has done in relation to the road or whether its actions are sufficient to manifest intent to abandon.

Once a road has been created, allowing abandonment only by governmental declaration makes the legal status of a road more certain, better ensures the public can assert its interest in preserving the road, and requires a decision by the proper elected officials. ${ }^{219}$ Some states do require such an express decision by the county's governing body. ${ }^{220}$ However, a statute may not require a formal decision

a section line [right-of-way], '[t]he appropriate governing board must act affirmatively[.]'” (citations omitted)).

217. See Soup Creek LLC v. Gibson, 439 P.3d 369, 376 (Mont. 2019) (citing court's previous statement that abandonment requires "some affirmative official act, and not mere implication," then clarifying that "[a]bandonment of . . a public highway required affirmative action by authorized government officials" (citations omitted)).

218. Illinois allows abandonment without a statutory decision "only where the public has acquired the legal right to another road or where the necessity for another road has ceased to exist. ... This additional burden is imposed because a road is an indispensible [sic] public necessity that the public would not abandon without replacing." Chamness, 15 N.E.3d at 502-03 (citations omitted). This rule theoretically avoids finding abandonment when it would significantly injure the public. Similarly, Missouri does not allow abandonment by nonuse when a roadway is the only way to access a person's private land. See Burris v. Mercer Cty., 252 S.W.3d 199, 201-02 (Mo. Ct. App. 2008).

219. See Lower Twp. v. Reeves, 81 A.2d 513, 514 (N.J. Super. Ct. Ch. Div. 1951) (“Once having been dedicated to the public use, the right of the public in the highway becomes irrevocable. ... The Legislature alone has the power to release the dedicated lands and discharge the public, and the interest of the public in such highway may be lost only upon a formal vacation or abandonment by a duly constituted authority, in the mode and manner prescribed by the law." (citations omitted)).

220. See, e.g., IDAHO CODE $§ 40-203(1)$, (5) (2020) (“All other highways or public rights-ofway [other than those "created solely by a particular type of common law dedication . . . that was not recorded in the official records of an Idaho county"] may be abandoned and vacated only upon a formal determination by the commissioners pursuant to this section that retaining the highway or public right-of-way for use by the public is not in the public interest . . . ."); 605 ILL. ComP. Stat. 5/5-109 (2020); N.J. Stat. AnN. § 27:16-28 (West 2020); Utah Code AnN. § 72-5-105 (West 2020) ("[A]ll public highways, streets, or roads once established shall continue to be highways, streets, or roads until formally abandoned or vacated by written order, resolution, or ordinance resolution of a highway authority having jurisdiction or by court decree . . .."); VT. Stat. ANN. tit. 19, § 710 (2020); Wyo. STAT. ANN. § 24-3-101 (2020); Erickson v. Clancy Realty Tr., 43 N.E.3d 322, 325 (Mass. App. Ct. 2016) (“As a general rule, in the absence of an express 
even though it may seem to do so. Colorado's statute says a public roadway "shall not be vacated by any method other than a resolution approved by the board of county commissioners of the county." ${ }^{221}$ But Colorado courts have reasoned that abandonment is different from vacation and therefore have also recognized termination of a public roadway by common law abandonment. ${ }^{222}$ Whether the exclusive means to terminate a roadway or not, state statutes authorizing termination of a roadway by resolution typically require the same process as required for creating a public road: notice, hearing, and a resolution. ${ }^{223}$ The state statute typically will also specify a standard for deciding to abandon a public road, such as Georgia's requirement that the road "has for any reason ceased to be used by the public to the extent that no substantial public purpose is served by it or that its removal from the county road system is otherwise in the best public interest." ${ }^{224}$

Some states give courts the authority to vacate public roads - some with specified criteria, some without. ${ }^{25}$ The typical considerations for the court, whether specified or not, include the public need for the road and whether there

discontinuance, a road is not discontinued by implication.”); Soup Creek LLC, 439 P.3d at 376 ("[A] public highway cannot be abandoned by anything short of an order by the commissioners, operation of law, or court order."); Lower Twp., 81 A.2d at 514; Hoyt v. Hull, 677 N.E.2d 377, 380 (Ohio Ct. App. 1996) ("There was no dispute that County Road 21A was originally an established public road; therefore, it could be vacated only in compliance with R.C. Chapter 5553 . ..."); State v. Harvey Real Estate, 57 P.3d 1088, 1092 (Utah 2002) ("These statutes unambiguously establish that all public highways remain as such unless they are officially abandoned or vacated by order of the proper authority. They make no allowance for any other type of abandonment or vacation." (citation omitted)); Benson v. Hodgdon, 992 A.2d 1053, 1059 (Vt. 2010); Carnahan v. Lewis, 273 P.3d 1065, 1077 (Wyo. 2012); Sheridan Cty. v. Spiro, 697 P.2d 290, 303 (Wyo. 1985); White, 547 P.2d at 1199 .

221. Colo. Rev. StAT. § 43-2-303(2)(b) (2020).

222. See Bittle v. CAM-Colorado, LLC, 318 P.3d 65, 70 (Colo. App. 2012); Bd. of Cty. Comm'rs v. Kobobel, 74 P.3d 401, 406-07 (Colo. App. 2002).

223. See, e.g., Ala. Code § 23-4-2 (2020); Colo. Rev. Stat. § 43-2-303(2)(b) (2020); Conn. Gen. Stat. § 13a-49 (2020); GA. Code ANN. § 32-7-2(b) (2020); S.D. Codified Laws §§ 31-3-6 to -7 (2020).

224. Ga. Code AnN. § 32-7-2(b)(1) (2020); see also Ohio Rev. Code AnN. § 5553.04 (West 2020) ("[W]hen the board of county commissioners is of the opinion that it will be for the public convenience or welfare to locate, establish, alter, widen, straighten, vacate, or change the direction of a public road, it shall so declare by resolution ....").

225. See, e.g., Conn. Gen. Stat. § 13a-50 (2020) ("The Superior Court, on the application of any person, may discontinue any highway in the judicial district where it is held, which cannot be discontinued by the selectmen; but all questions arising as to the convenience or necessity of such highway shall, unless the parties agree, be decided by a committee to be appointed by the court; and any person may appear and be heard in relation to such application . . .."); DEL. CODE ANN. tit. 17, § 1301(a) (2020) ("The Superior Court shall have jurisdiction to vacate public roads, bridges and all other rights-of-way ....”); Soup Creek LLC, 439 P.3d at 376 (see supra note 220). 
is a need to vacate it. ${ }^{226}$ Lack of significant benefit alone shouldn't justify abandonment, because the road is still a valuable property right and may become more useful in the future. A court charged with such authority should abandon a road only if there is some need to vacate the road that outweighs its present and potential benefits. ${ }^{27}$ Such needs may include that the road is dangerous, inconvenient, obstructing desirable development, or costs more to maintain than it is worth. ${ }^{228}$

When a road is abandoned, title to the roadway generally reverts to the landowners. ${ }^{229}$ When the road passes along the boundary line between parcels of land, the owners own up to the center line of the roadway. ${ }^{230}$

\section{CONCLUSION}

The uncertain legal status of old, rarely used county roads creates problems for the government and private property owners alike. A county government may be unsure whether it has an obligation or even the option to maintain such a road. Private property owners, or prospective buyers of private property, may be unsure whether they can obstruct or otherwise close a road. The rules for acquiring public rights to a roadway, legally establishing a public road, and giving notice of a public road should at least be clear and consistent. But they should also be sensitive to the circumstances of rural roads and property owners and favor more clarity and specificity. Dedication should require clear expressions of intent to dedicate, not just acquiescence to public use, and clear acceptance of dedication by the county to avoid unwanted and unmaintained public roads. Prescriptive roadways should require evidence of governmental control, not just use by members of the public, to protect both the private owner from loss of property rights simply from being neighborly and the government from unexpected obligations to maintain unwanted roads. Statutes should require recording of the

226. See In re Duffy, 444 A.2d 301, 302 (Del. Super. Ct. 1982) (“Obviously such authority cannot be exercised arbitrarily, but must be based upon the sound discretion of the Court. In such situations the usual test is to consider the necessity of the road as a public utility. It is sometimes stated that a highway may be vacated only when it can be determined that such road is no longer required for public use or convenience and that there is a public need for its vacation, or that the vacation of the road will inure to the public benefit or use." (citations omitted)); Stahl Soap Corp.

v. City of N.Y., 156 N.E.2d 443 (N.Y. 1959).

227. See Duffy, 444 A.2d at 302.

228. See id.

229. See, e.g., Ky. Props. Holding LLC v. Sproul, 507 S.W.3d 563, 571 (Ky. 2016); R \& S Dev., Inc., v. Wilson, 534 So. 2d 1008, 1011 (Miss. 1988); Holmquist v. King Cty., 328 P.3d 1000, 1006 (Wash. Ct. App. 2014).

230. See, e.g., La. Stat. AnN. § 48:701 (2020); UtAh Code AnN. § 72-5-105(2) (West 2020); Glidden v. Belden, 684 A.2d 1306, 1312 (Me. 1996) ("The common law doctrine of abandonment vests title in abutting landowners to the center line of a public way when the way is abandoned."); Dalton Twp. v. Muskegon Cty. Bd. of Cty. Rd. Comm'rs, 565 N.W.2d 692, 694 (Mich. Ct. App. 1997). 
establishment of public roads, or at least some other central, comprehensive, and accessible public record of public roads, to ensure that rural property owners and buyers can correctly and confidently determine the status of a road. Likewise, public roads should not be vacated simply by unrecorded inaction, but only by official decisions to vacate. Such rules can't eliminate all uncertainties about the legal status of rural roads, but they certainly can reduce them and make them easier to resolve. 